\title{
South Eveleigh Community Rooftop Garden (SECRG) Methods
}

\section{Research Fellows:}

Linda Corkery, FAILA, RLA, ASLA (Intl)

Professor, Landscape Architecture, UNSW Built Environment

University of New South Wales

Sara Padgett Kjaersgaard, PhD, BLArch (hons), FAILA, RLA Lecturer, Landscape Architecture, UNSW Built Environment University of New South Wales

\section{Research Assistant:}

Lisa Thomson, BLArch (hons)

MPhil Candidate

University of New South Wales

\section{Firm Liaisons:}

Clarence Slockee (former co-founder of Yerrabingin Pty Ltd)

Director

Jiwah Pty Ltd

Matt McKay

Project Support

Jiwah Pty Ltd

This investigation was conducted as part of the Landscape Architecture Foundation's 2020 Case Study Investigation (CSI) program. CSI matches faculty-student research teams with design practitioners to document the benefits of exemplary high-performing landscape projects. Teams develop methods to quantify environmental, social, and economic benefits and produce Case Study Briefs for LAF's Landscape Performance Series.

The full case study can be found at: https://landscapeperformance.org/case-studybriefs/south-eveleigh-rooftop

To cite:

Corkery, Linda, Sara Padgett Kjaersgaard, and Lisa Thomson. "South Eveleigh Community Rooftop Garden Methods." Landscape Performance Series. Landscape Architecture Foundation, 2020. https://doi.org/10.31353/cs1681 


\section{Acknowledgements}

We acknowledge the Gadigal people of the Eora nation as the traditional custodians of the unceded land where the South Eveleigh Community Rooftop Garden is located. We acknowledge Elders past and present for their contribution and knowledge of this land.

This case study was undertaken in collaboration with Indigenous practice partner Jiwah. One of the core principles that have underpinned the development and collaboration of this case study is the concept of 'give back'. Give back is a core principle of Aboriginal and Torres Strait Islander cultures. Our research partners are committed to sharing the knowledge that was shared with them, with other Indigenous and non-Indigenous people. Our partners see themselves as custodians of this knowledge for a short period of time. They have an obligation to share their knowledge to ensure other Indigenous people learn from their knowledge and that this knowledge is not lost. The principle of 'give back' recognizes that Indigenous Knowledge does not belong to an individual, because knowledge has been derived and accumulated from the knowledge of others.

We recognize and respect the ethical and moral responsibility we have when collaborating cross culturally with our Indigenous partners and acknowledge and respect their right to selfdetermination. We have been guided by their ways of sharing knowledge with us, and we support the way they choose to share the results of the case study with others.

We gratefully acknowledge the input and support of our research partner and team from Jiwah: Clarence Slockee, Matt McKay, Kyle Leonard, and Lyle Hunt.

We are grateful to William Walker, Project Director Mirvac, South Eveleigh Precinct, for his early support of the project and facilitation of contacts within the precinct to assist us with our research. Also to Hisham Alameddine from Junglefy for his insights into the construction and design of the rooftop. 


\section{Context}

\section{Context: Indigenous Nation}

The site is situated on Gadigal land of the Eora nation.

(https://gambay.com.au/map/Eora/554)

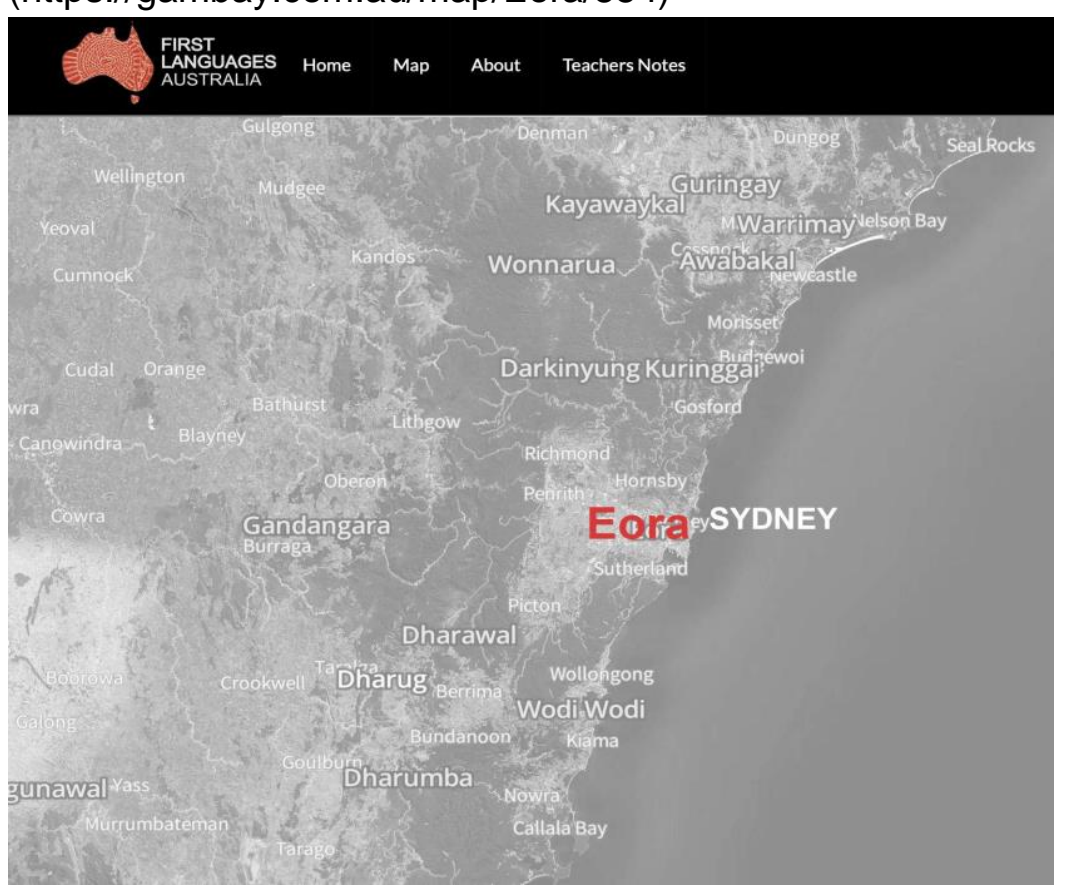

\section{Context: City}

South Eveleigh is situated 2.17 miles $(3.5 \mathrm{~km})$ from Sydney Central Business District (CBD), an inner city, urban environment.

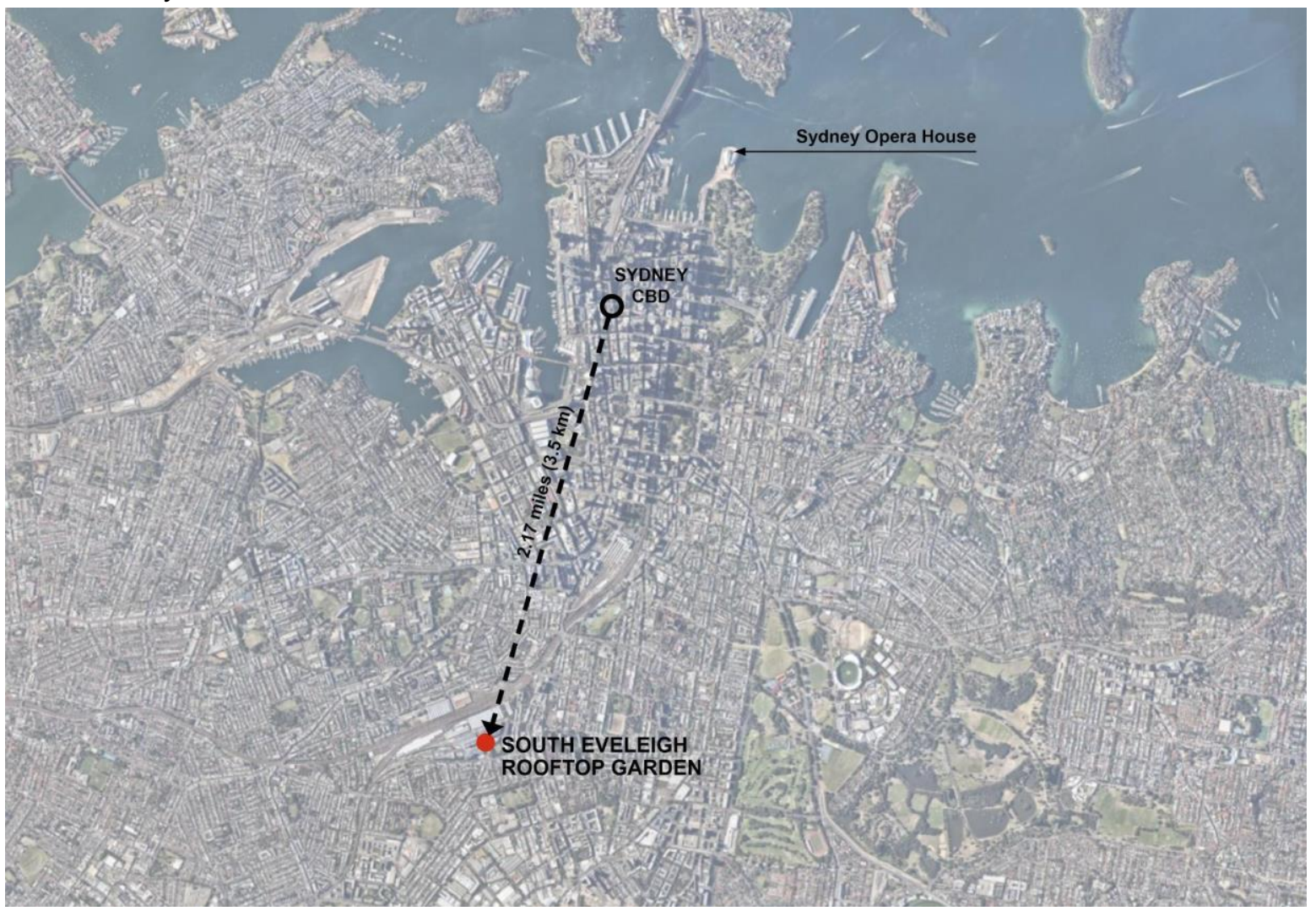




\section{Context: Neighborhood}

South Eveleigh Community Rooftop Garden (SECRG) is part of the Australian Technology Park development in the industrial heritage areas of South Eveleigh, adjacent to the residential suburb of Redfern.

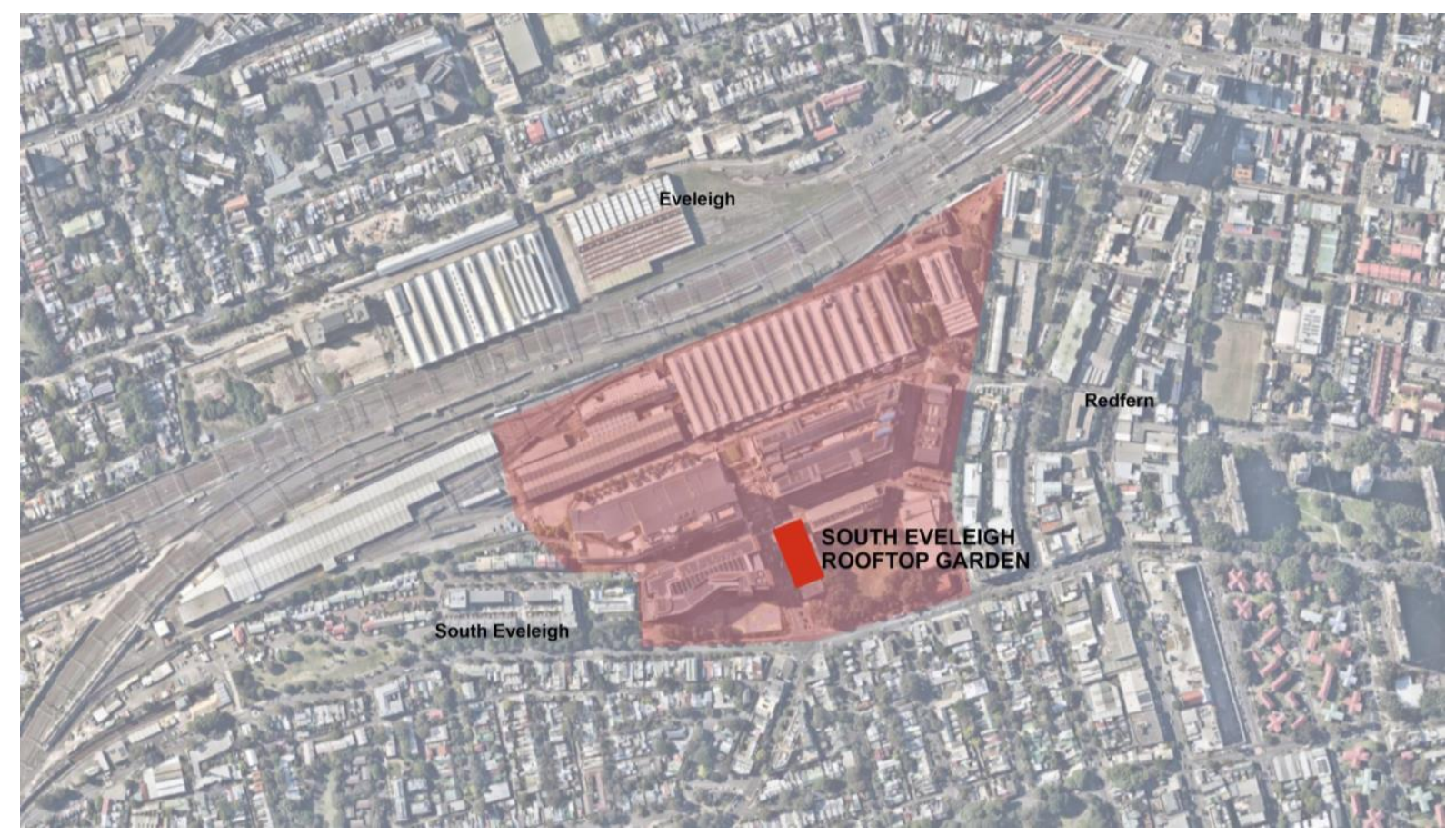

\section{Context: Street}

The garden is located on the rooftop of a four-story community building in the South Eveleigh Precinct. The rooftop sits adjacent to canopy trees in Eveleigh Green park. The rooftop offers a visual amenity and passive recreation for office workers in the surrounding office buildings. The rooftop has a large bank of solar panels on its southern side.

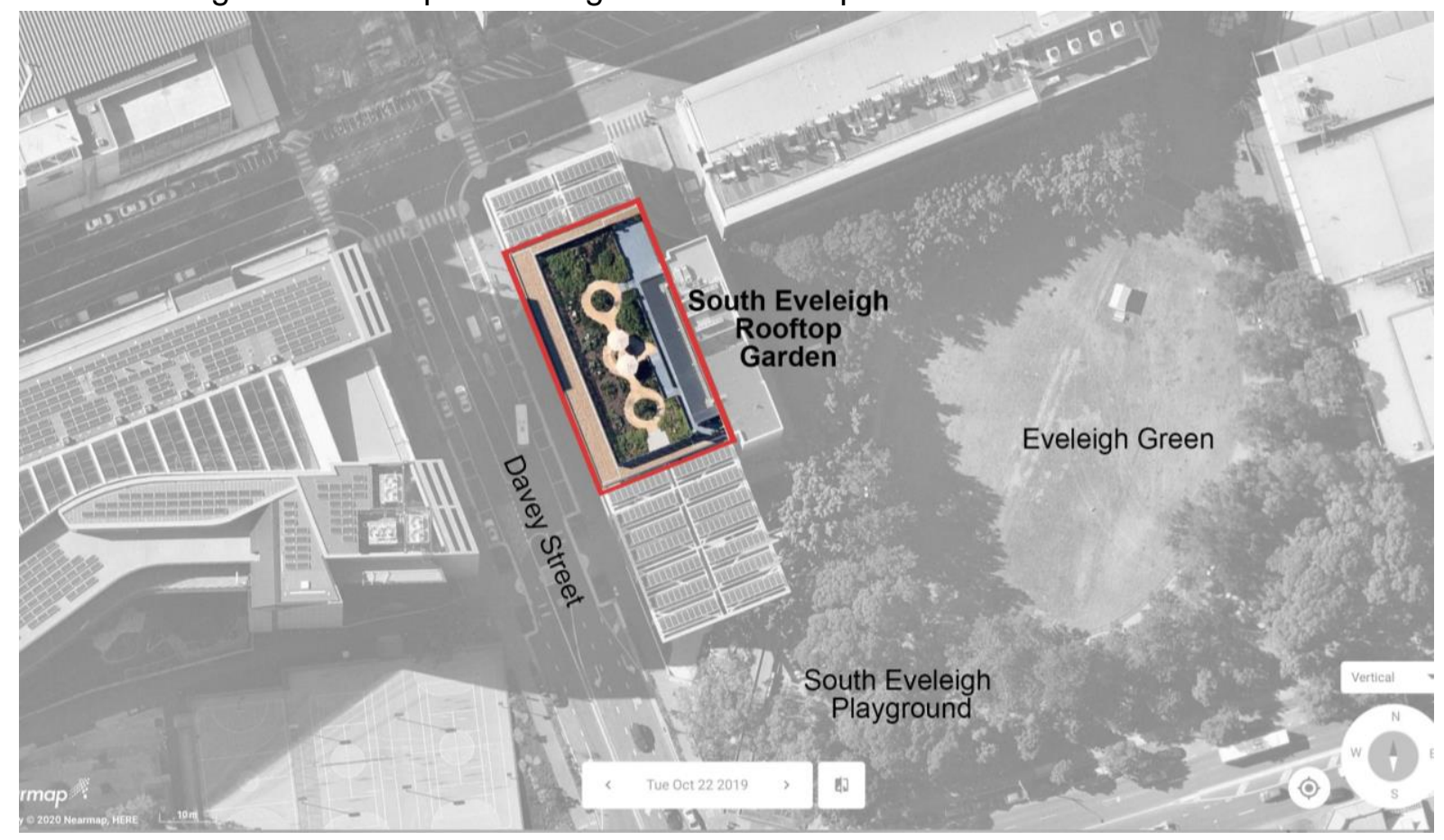




\section{Research Strategy/Overview}

The LAF Case Study Investigation program requires an evaluation of economic, environmental, and social benefits. However, a large component driving the developer's brief for the SECRG was the focus on social sustainability. While there are many possible environmental and economic benefits to measure for this project, such as thermal control and subsequent heating and cooling energy use reductions for the building, as well as stormwater management, the research team resolved these were intrinsic to any green roof rather than specific to this project's goals. Furthermore, there is a wide range and established literature and data on these aspects of green roofs readily available. The research team wanted to identify how an Indigenous-designed, operated, and maintained space delivers, and even expands upon, LAF's performance benefits.

The secondary sources shared by our research partner Jiwah, as well as the developer, project manager, and landscape construction firm clearly demonstrated an opportunity for the academic team to assess the social performance of the project. Primary observation data was collected to determine the environmental performance related to species richness and diversity. While content analysis of social media and segmentation of qualitative data from a survey were useful in measuring the broader impact and interest generated by the project, what was of most value were the many meetings we had with the Indigenous operators that allowed trust and confidence to develop and, subsequently, facilitated the sharing of cultural knowledge.

While the academic team had planned to conduct in-depth surveys with visitors to the rooftop garden in 2020, the restrictions associated with the COVID-19 pandemic, including limitations on public activity and physical distancing requirements, resulted in the closure of the rooftop in March 2020. This impacted our ability to conduct these within the timeframe. We decided to distribute the survey electronically which resulted in low levels of response. 


\section{Environmental Benefits}

- Increases pollinator insect species richness on the previously bare rooftop, with a total of 131 pollinators representing at least 13 pollinator species observed over 3 days in spring 2020 . The pollinator trellis feature attracted $36 \%$ of the pollinator insects observed (and had the highest vegetation volume at $54 \%$ ). There was a $116 \%$ increase (from 30 to 65 ) in the number of native plant species from initial planting to 2 years after construction.

\section{Background:}

The findings of Threlfall et al., (2017) determined that increasing the native planting volume in urban green spaces can improve biodiversity outcomes. In their 2017 study, they found a 30-120\% higher occupancy for bats, native birds, beetles and bugs when there was an increase in native plant understory volumes from $10 \%$ to $30 \%$. Their study also determined a $10-140 \%$ higher occupancy across all native taxa when the proportion of native to nonnative vegetation increased from $10 \%$ to $30 \%$. For this study, the proportion of native to nonnative vegetation is not relevant because the rooftop garden consists of $100 \%$ native vegetation.

Threlfall et al., (2017) demonstrated that at the city-wide level, any increase in native vegetation can have a positive influence on species richness. Furthermore, the diversity of native plant forms and floral abundance (volume) were the highest-ranking predictors of pollinator species richness. Their study concludes that even small scale, urban green spaces with complex native vegetation, such as green roofs, provide the opportunity to create native biodiversity in cities and potentially influence the composition of urban food webs.

In accordance with Indigenous Knowledge sharing protocols, we agreed not to publish the full planting list and undertake methods that revealed the diversity of planting types. Instead we used flora abundance as our indicator of the benefit.

\section{Method:}

We used the AutoCAD drawing (.dwg) of the garden's site plan to draw a polygon around the edge of the rooftop to determine the total area of the rooftop (6028 sq ft) and the planted garden (4219 sq ft) (see Figure 8).

We used the method developed by Threlfall et al., (2017) to determine the flora abundance (vegetation volume) of the rooftop garden. In order to determine vegetation volume, we overlaid the rooftop garden with a virtual grid. The grid consisted of eight (8), parallel transect lines, located 16.4 feet apart, set out in an east to west direction. While Threlfall et al.,'s method plotted intervals at 3.28 feet, we plotted 6.56 feet along each transect line, beginning with the eastern side of the garden due to the relatively small size of the garden. Seven (7) grid intervals were located along each transect. The area surveyed for each grid point was 8.50 sq feet in size.

We needed to be able to clearly identify each grid point so we could ensure a precision with the location of vegetation volume, and the corresponding reference for the pollinator counts to be taken during the Australian springtime. We allocated a color to each of the transect lines (orange, red, purple, blue, green, yellow, orange, red) beginning with the most northern 
transect. We placed the corresponding colored popsicle stick into the rooftop growing medium, at 6.56 feet intervals along each transect. We then allocated a number to each grid location and wrote this onto the popsicle stick. In total, we had 56 grid locations, identifiable by their colored popsicle stick and number (see Figure 1 and 2).

\section{Figure 1: Location of transects and grid points on the rooftop}

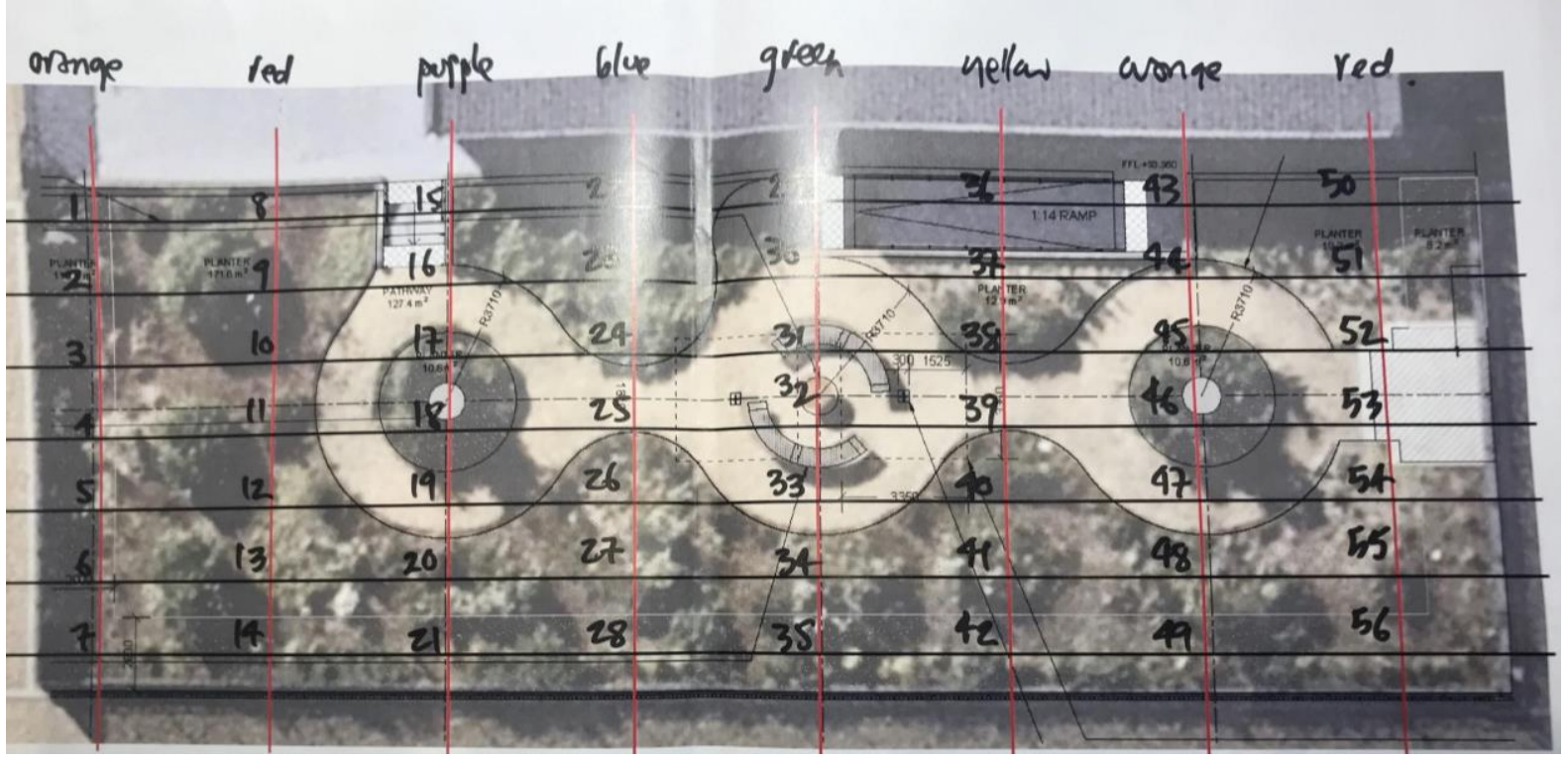

Figure 2: Research Assistant Lisa Thomson plotting transects and grid points on the rooftop garden

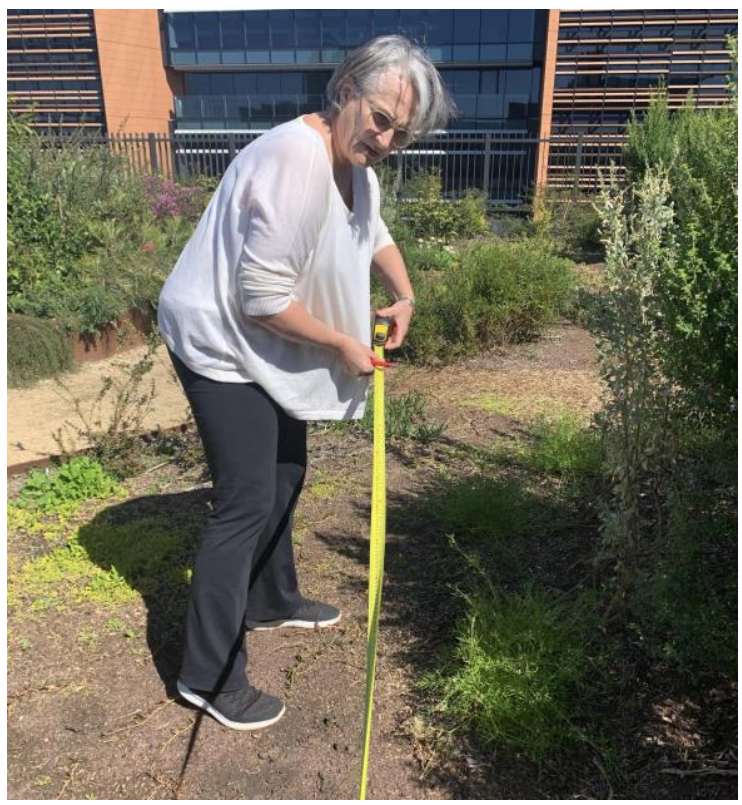




\section{Figure 3: Research Assistant Lisa Thomson determining the vegetation height of a grid point on the rooftop garden.}

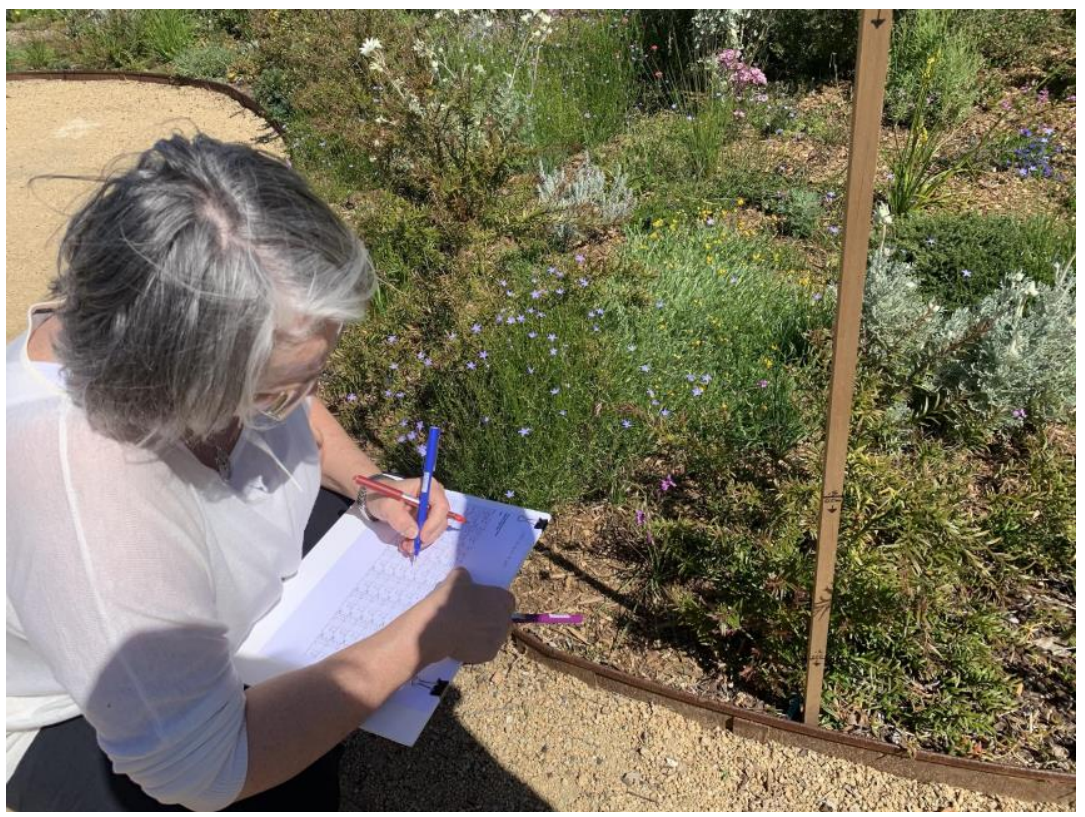

We calculated the vegetation volume for each of the 56 grid points on the rooftop. We did this by recording the vegetation intercepting a vertical pole at each grid point (see Figure 3 ). The following vegetation height intervals were used $0.0-0.66 \mathrm{ft}(0.0-0.2 \mathrm{~m}) ; 0.66-1.64 \mathrm{ft}(0.2-$ $0.5 \mathrm{~m}) ; 1.64-3.28 \mathrm{ft}(0.5-1.0 \mathrm{~m}) ; 3.28-6.56 \mathrm{ft}(1.0-2.0 \mathrm{~m})$; and $>6.56 \mathrm{ft}(>2 \mathrm{~m})$ (Threlfall et al., 2017 pp.1875-1876). We used the center of each grid point to plot a 1.64 foot radius, and determine the circular area around the grid point. This circular area was used to calculate the vegetation volume for each grid point. We determined the number of species intersecting with each height interval on the pole for each of the 56 grid points (see Figure 3). Finally, we were able to calculate a summation value for each vegetation interval, and therefore determine the total vegetation volume of native species for each height interval on the rooftop garden. Understanding the total vegetation volume allowed us to determine the height interval that best supported pollinators and select grid point locations for pollinator studies (see Appendix 1, Tables 1 to 8).

We chose seven (7) of the 56 grid point locations to observe for our pollinator studies. (See Figure 4) These seven grid points were chosen to be representative of all the areas of the garden. Between them, they had varying native planting species numbers and types. The seven grid points also had variations in vegetation volume determined through the grid plot method above. One of the grid points, number 46 , is located at the center of a pollinator trellis - a landscape feature of the rooftop garden designed specifically to attract pollinators. Some of the seven grid points were located close to pathways, others were surrounded by a range of other native vegetation types. Each of the grid points chosen had varying degrees of native vegetation volume (see Figure 5). The selected grid points were numbers 1, 20, 23, 26, 41, 43 and 46. 
Figure 4: Location of pollinator observation sites in accordance with grid points on the rooftop

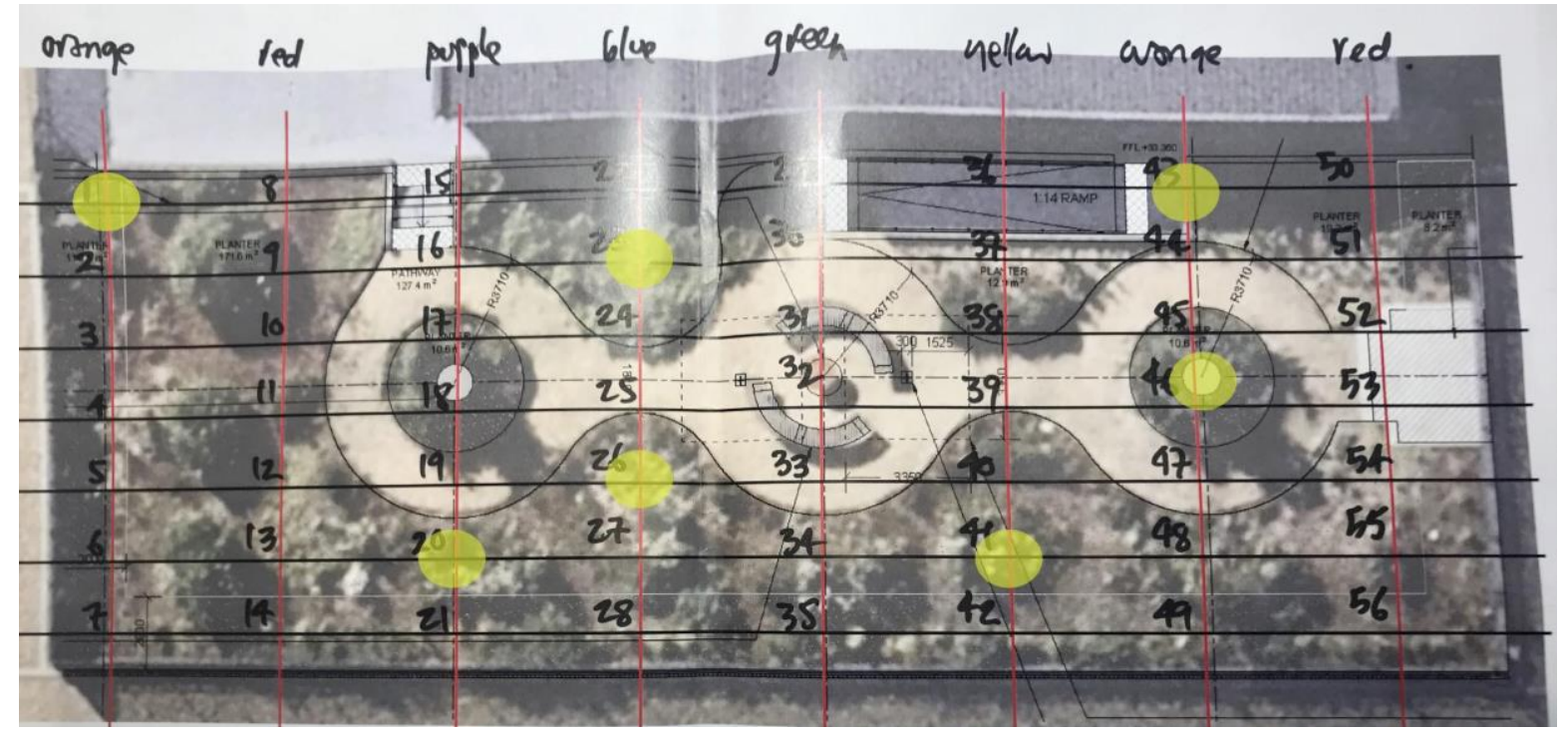

Figure 5: Vegetation volume (VvegHx) of selected grid points for insect pollinator studies

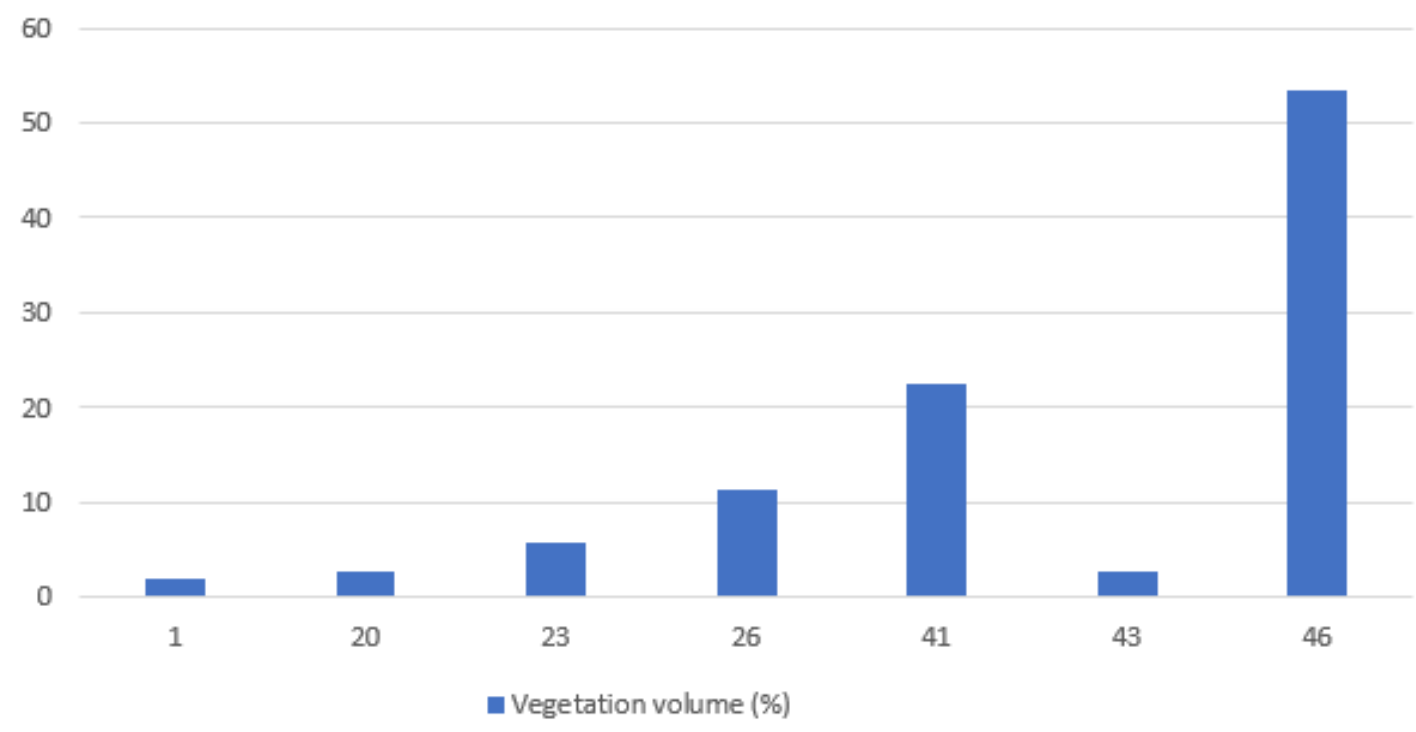

We hypothesized that we would find similar results to Threlfall et al. (2017), with the areas of the rooftop exhibiting denser vegetation volume displaying higher pollinator activity (Figure 9). In accordance with Indigenous Knowledge sharing protocols outlined to us by our research partner, we have chosen not to share the full species list used in the rooftop garden. This is because Indigenous Knowledge sharing in Australia occurs orally, with the right to access knowledge occurring over time once trust is built with non-Indigenous participants. Access to knowledge encourages people to participate in Indigenous education workshops, which we have confirmed as a social benefit in this study.

We used the Wild Pollinator Count (Figure 6) (see www.wildpollinator.com) method as this is a well-documented, easy to use, and replicable method undertaken annually during the Australian springtime (September through to November). This means the method can be 
repeated year-to-year outside of the LAF CSI period and contribute to a larger database of pollinator studies for the rooftop.

We chose warm, calm (not windy), sunny days during the Australian spring to undertake the pollinator count (see Figure 9). In total, we observed pollinator counts on three days in 2020, September 7, September 21 and October 2. The date, time and weather conditions were recorded on the tally sheet for each of the seven grid points. We identified, documented and photographed the plant species at each grid point. Each pollinator count was carried out over a 10-minute period. We watched the flower/s continuously for 10 minutes and recorded the total number of pollinator species $(n)$ and diversity of pollinator species types (see Figure 7) that visited the flowers and moved around the stamen or pistil. We identified the predominant species type (i.e. wasp, bee, butterfly, beetle), and any descriptions of the observed pollinator to help us differentiate between different species. We were able to identify at least 13 different pollinator species.

Figure 6: Image of the Wild Pollinator Count Tally Sheet

(Source: https://wildpollinatorcount.com/resources/printable-tally-sheet/)

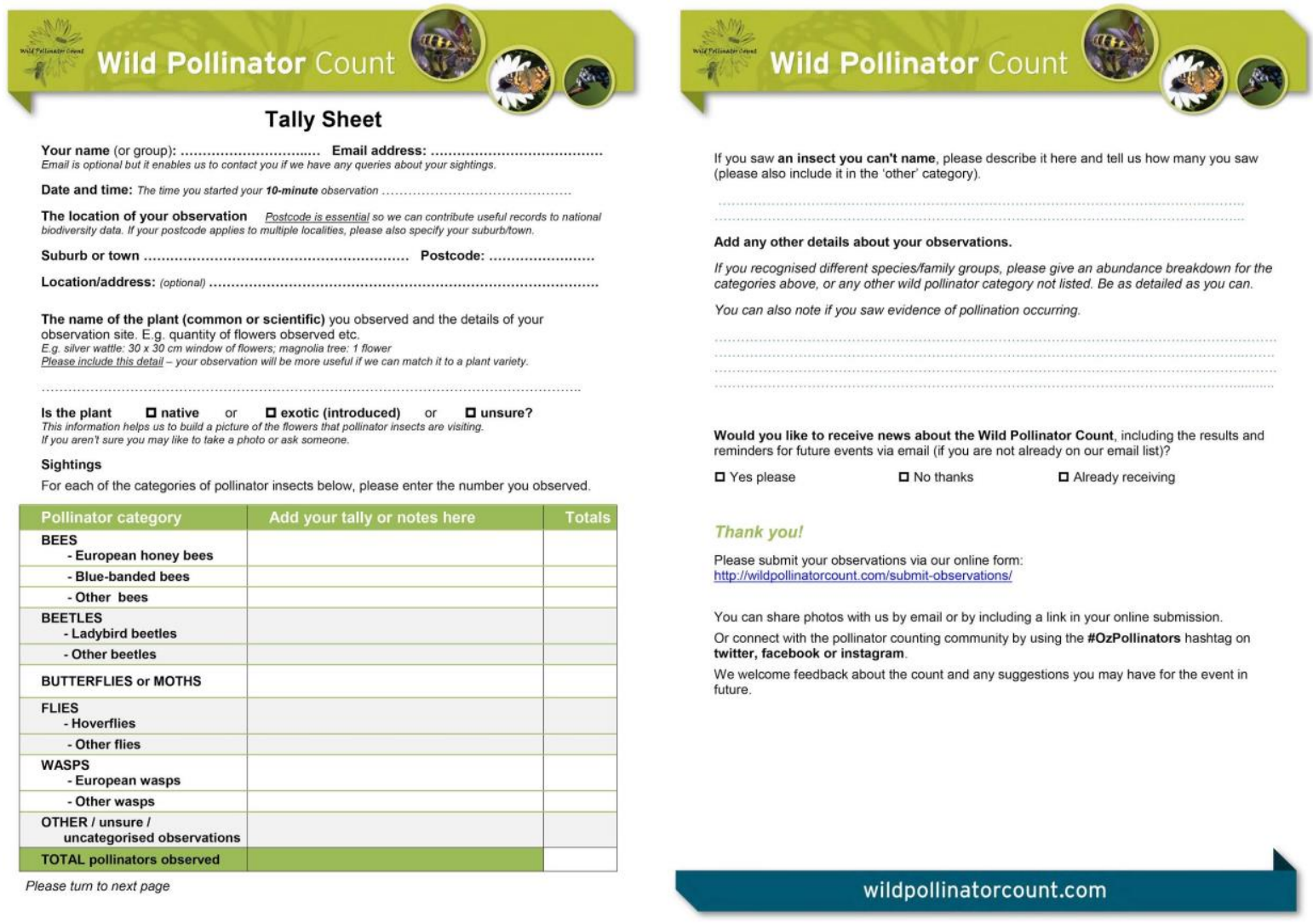


Figure 7: Photos of some of the pollinator species observed on the rooftop. (photo credit: Matt McKay)

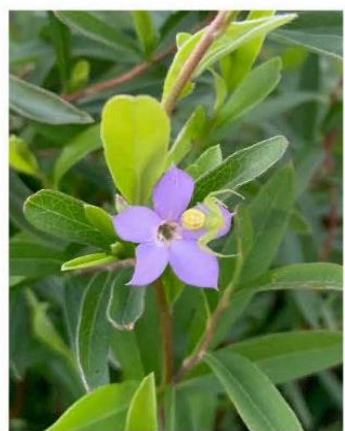

Flower Spider:

Green and Yellow spider

(Diaea evanida)

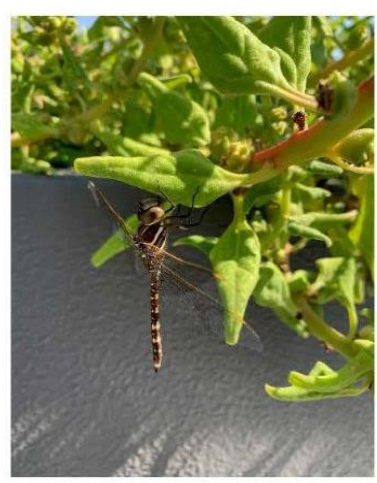

Dragonfly:

Swamp Tiger-tail

(Synthemis eustalacta)

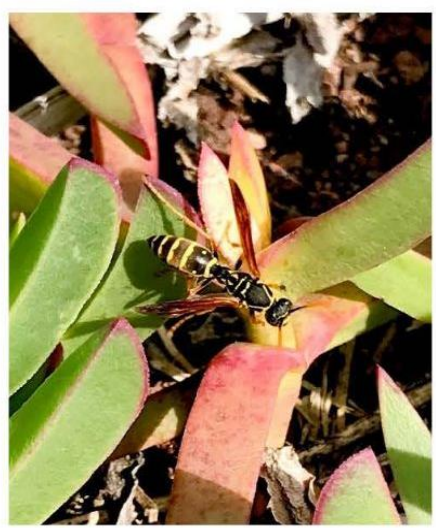

Wasp:

Asian Paper Wasp

Polistes chinensis

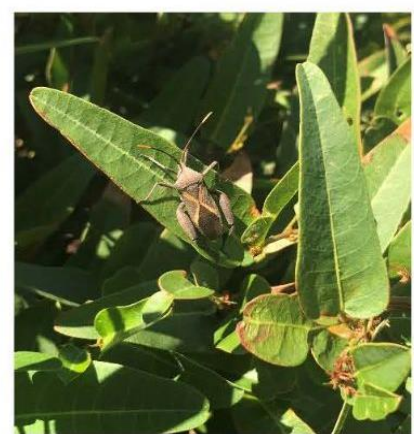

Beetle:

Crusader Bug

(Mictis profana)

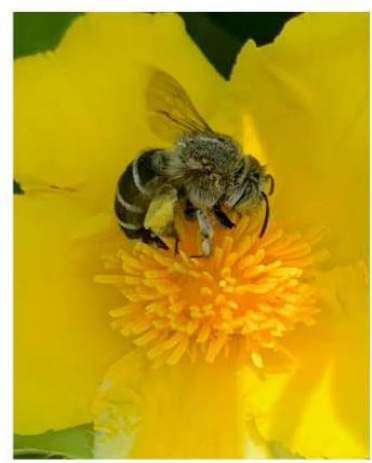

Bee:

Blue-banded Bee

(Amegilla cingulate)

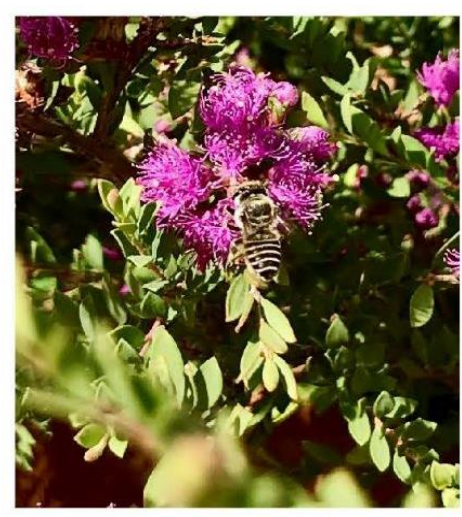

Bee:

Leaf cutter resin Bee

Megachile $x$

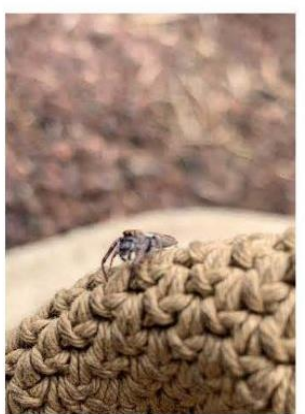

Spider:

Jumping Spider

(Opisthoncus $x$ ) 


\section{Calculations}

Total area of planted rooftop garden:

Area of rooftop $=6028 \mathrm{sq} \mathrm{ft}$

Area of garden bed $=4219 \mathrm{sq} f t$

Percentage of roof covered in garden bed $=(4219 / 6028) \times 100=70 \%$

Figure 8: Diagram of rooftop garden planting area
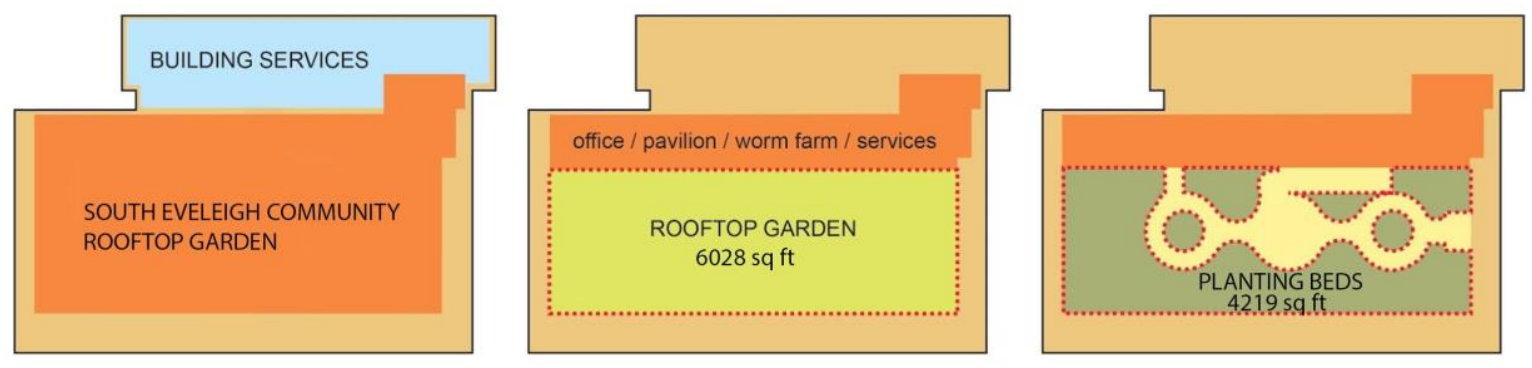

Determine the increase in native planting species numbers since construction:

$100 \times$ (final - initial)/ initial

$=100 \times(65-30)$

$=\mathbf{1 1 6} \%$ increase in native planting species from February 2019 to March 2021

Calculate the vegetation volume of the $\mathbf{5 6}$ grid point locations: See Appendix 1 for calculations

Determine the vegetation volume (VvegHx) of the selected grid points for pollinator studies): See Table 9 


\begin{tabular}{|c|c|c|c|c|c|c|}
\hline \multirow[t]{2}{*}{$\begin{array}{l}\text { Grid } \\
\text { Reference }\end{array}$} & \multicolumn{5}{|c|}{$\begin{array}{l}\text { Height variable } \\
\text { Number of times vegetation intercepted } \\
\text { the pole }[\mathrm{Pn} 1 \mathrm{Hx}]\end{array}$} & \multirow{2}{*}{$\begin{array}{l}\text { Vegetation Volume of individual pollinator grid plots } \\
\mathrm{VxegH \textrm {Hx }}=((\Sigma \mathrm{Pn} 1 \mathrm{Hx} / \mathrm{PtH}) \times \mathrm{Vs} \mathrm{Hx}) \\
\mathrm{Vs \textrm {Hx }}[0.0-2.0]\end{array}$} \\
\hline & $\begin{array}{l}0.0- \\
0.2 \mathrm{~m}\end{array}$ & $\begin{array}{l}0.2- \\
0.5 \mathrm{~m}\end{array}$ & $\begin{array}{l}0.5- \\
1 \mathrm{~m}\end{array}$ & $1-2 m$ & $>2 m$ & \\
\hline 1 & $x x$ & $x x$ & $x x$ & $x$ & 0 & $\begin{array}{l}7 / 56 \times(0.79 \times 2) \\
=0.0197 \times 100 \\
=1.98 \%\end{array}$ \\
\hline 20 & $x$ & 0 & 0 & 0 & 0 & $\begin{array}{l}1 / 56 \times(0.79 \times 2) \\
=0.0282 \times 100 \\
=2.82 \%\end{array}$ \\
\hline 23 & $x$ & $x$ & 0 & 0 & 0 & $\begin{array}{l}2 / 56 \times(0.79 \times 2) \\
=0.057 \times 100 \\
=5.69 \%\end{array}$ \\
\hline 26 & $x x x$ & $x$ & 0 & 0 & 0 & $\begin{array}{l}4 / 56 \times(0.79 \times 2) \\
=0.113 \times 100 \\
=11.28 \%\end{array}$ \\
\hline 41 & $x x x x$ & $x x x$ & $x$ & 0 & 0 & $\begin{array}{l}8 / 56 \times(0.79 \times 2) \\
=0.228 \times 100 \\
=22.57 \%\end{array}$ \\
\hline 43 & $x$ & 0 & 0 & 0 & 0 & $\begin{array}{l}1 / 56 \times(0.79 \times 2) \\
=0.0282 \times 100 \\
=2.82 \%\end{array}$ \\
\hline 46 & $x x x x x$ & $x x x x x$ & $x x x x x$ & $x x$ & $x x$ & $\begin{array}{l}19 / 56 \times(0.79 \times 2) \\
=0.536 \times 100 \\
=53.6 \%\end{array}$ \\
\hline
\end{tabular}

Table 9: Vegetation volume (VvegHx) of the selected grid points for pollinator studies

Calculate insect pollinator species richness for the selected grid points

Calculate the total number of pollinator species observed for each of the seven grid points:

See Appendix 2 for calculations.

Figure 9: Total number of individual pollinator species $(n)$ observed at each grid point location insect over three spring days in $\mathbf{2 0 2 0}$

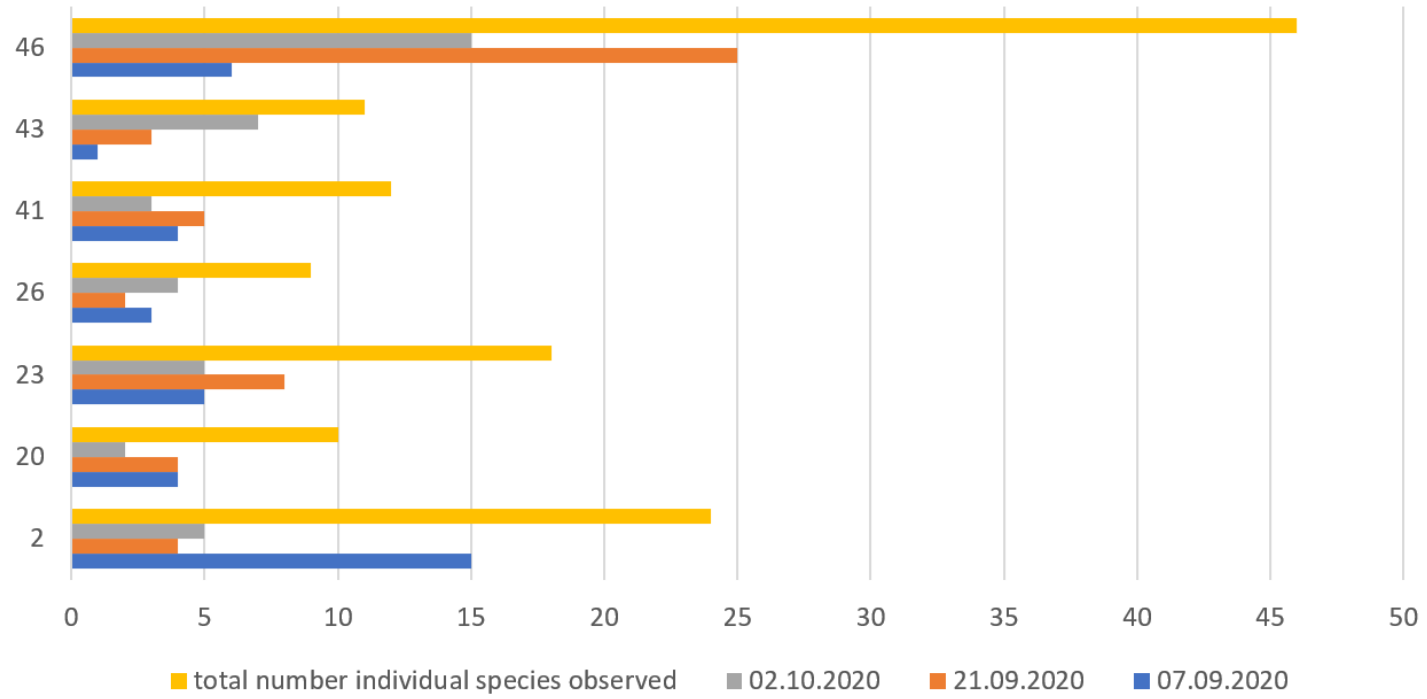


Total number of individual pollinator species observed $(n)=131$

\section{Sources}

Academic references on green roofs adding to urban biodiversity

- Threlfall, C.G., Walker, K., Williams, N.S.G., Hahs, A.K., Mata, L., Stork, N., Livesley, S.J., 2015. The conservation value of urban green space habitats for Australian native bee communities. Biological Conservation 187, 240-248. https://doi.org/10.1016/j.biocon.2015.05.003

- Threlfall, C.G., Mata, L., Mackie, J.A., Hahs, A.K., Stork, N.E., Williams, N.S.G., Livesley, S.J., 2017. Increasing biodiversity in urban green spaces through simple vegetation interventions. Journal of Applied Ecology 54, 1874-1883. https://doi.org/10.1111/1365-2664.12876

- Threlfall, Caragh G., Alessandro Ossola, Amy K. Hahs, Nicholas S. G. Williams, Lee Wilson, and Stephen J. Livesley. 'Variation in Vegetation Structure and Composition Across Urban Green Space Types'. Frontiers In Ecology And Evolution 4 (2016). Accessed doi:10.3389/fevo.2016.00066.

- Bulbert and Ginn, 2007 Quick Invertebrate Guide: An introduction to identifying Australian invertebrates' https://media.australian.museum/media/dd/Uploads/Documents/9379/Quick+Inverteb rate+Guide.4e16695.pdf

\section{Limitations:}

The Wild Pollinator Count is an Australia citizen science program which runs during the specific dates of 12-19 April (Autumn) and 8-15 November (Spring). We were unable to undertake the wild pollinator count during the Autumn period because of COVID-19 restrictions. Due to the LAF submission deadline, we were unable to undertake counting during the Spring dates. We chose September and October to undertake the pollinator counts, because the weather was starting to warm up, our research partner had begun to observe pollinator activity in the garden, and it allowed us to meet our LAF deadline.

We did not have the expertise to identify individual pollinator species types. We were able to identify that the observed pollinators belonged to specific groups (i.e. bees, beetles, spiders). We provided short-hand descriptions of the species observed. This allowed us to identify and report a benefit of at least 13 individual species without expert opinion. With further understanding of pollinator species types, it is possible that the species types identified could be slightly higher.

We have elected not to provide the full plant species list because of our respect for Indigenous Knowledge sharing protocols. Our CSI partners have explained the importance of sharing Indigenous Knowledge orally, and over time as trust is built. Our partners encourage people seeking further knowledge about the rooftop garden to participate in Indigenous Knowledge workshops that support oral storytelling and knowledge sharing. 
- Diverted 5.16 tons of food waste, equivalent to the weight of 2.4 Grand Jeep Cherokees, from landfill within the first year of operation through collecting food waste from 3 local cafes. 7 on-site worm farm bins produced 89 gallons of liquid organic fertilizer for the rooftop garden (saving an estimated \$560 USD) and 2,778 Ibs of solid organic fertilizer for other precinct gardens (saving an estimated \$300 USD) within the first year of operation.

\section{Background:}

We understood from early conversation with our research partner, Jiwah, that there was a circular waste system occurring between the compost generated from three cafes within the precinct, and the worm farm bins located on the rooftop.

\section{Method:}

We sought to undertake semi-structured interviews with our research partner and the three cafe owners within the South Eveleigh precinct to determine the amount of food waste collected, and subsequently processed in the worm farm bins (See Figures 9 and 10). Our research partner identified the cafes, and our research assistant identified the cafe managers to interview. Unfortunately, only one of the three cafe managers was available to be interviewed due to the reduced trading hours required during the COVID-19 pandemic.

We used the quantitative information supplied by the cafe owner and our research partner to determine the volume of waste and by-product processed during the first year of operation. We approached the cafe manager via email to set-up a 30-minute meeting on Microsoft TEAMS. The email included our human ethics approval code, Participant Information and Consent Form, and the list of questions. Some time lapsed before the cafe owner provided a response. On November 112020 , the cafe manager provided a written response to the questions. The cafe manager's response confirmed that waste was weighed and taken to the rooftop garden worm bins three times a week by the kitchen staff. A total of 44 pounds of waste was supplied per week. (These are pre-COVID 19 figures.)

Our semi-structured interview regarding the food waste occurred with our research partner on June 19, 2020. Our research assistant documented this conversation and confirmed the figures provided in a follow-up email. Our research partner confirmed that three, 1.32 gallon buckets of food waste were received into the worm bins per day. This waste was the total cumulative waste from the three cafes across the precinct per day.

Our research partners explained that worm casting leachate, which is captured as a byproduct of the worm bin composting processes, can be reused as organic fertilizer within the rooftop and precinct gardens. Our research partners confirmed that each worm bin produced 2.11 gallons of liquid fertilizer every two months. Furthermore, for every $26.42 \mathrm{gal}$ of food waste processed, $30 \%$, or 7.93 gal is converted into worm castings. Worm castings can be used as organic fertilizer in and around garden beds to provide increased nutrients to the soil.

Prior to the COVID-19 pandemic, only seven of the ten worm bins were in operation. This suggests that there will be additional capacity of the rooftop garden to accept more organic food waste when food and beverage operations re-open within the South Eveleigh Precinct. 
Figure 9: Diagrams of Hungry composting operations as used on the SECRG.

(Source: Worm Farms Hungry Bins: https://www.hungrybin.co.nz/)

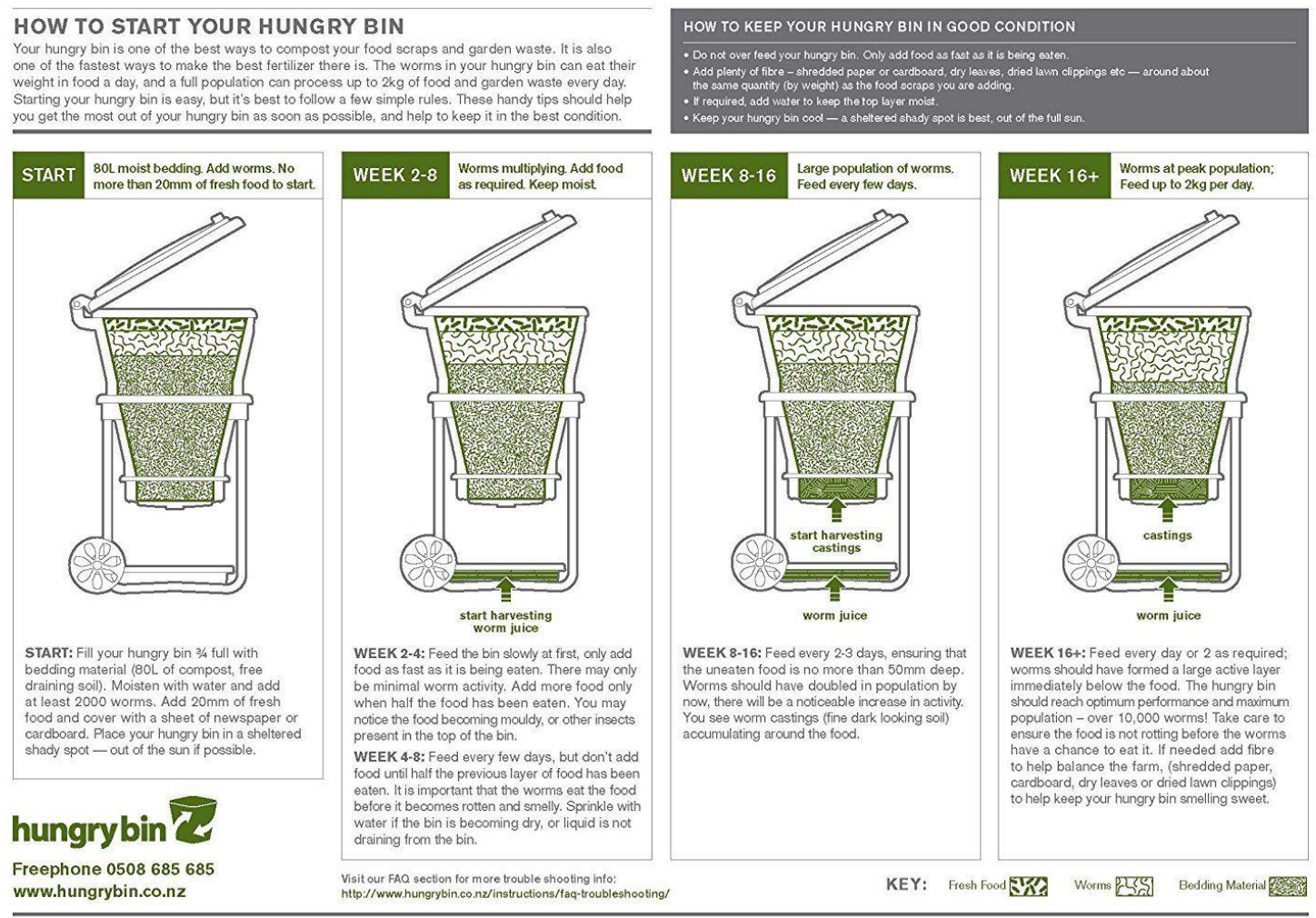

Figure 10: Our research partner Clarence Slockee (Jiwah) checking the worm bins (photo credit: Sara Padgett Kjaersgaard)

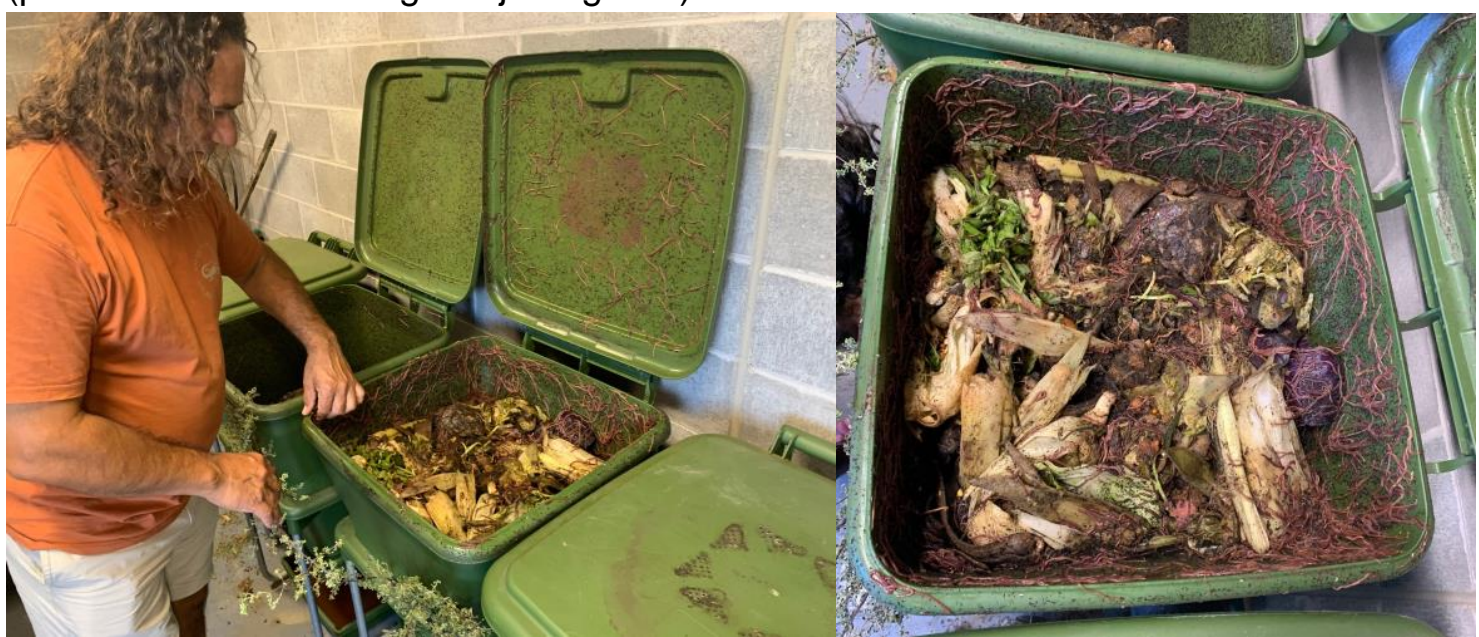

\section{Calculations:}

- Food waste: Based on seven of the ten composting bins being used during the first year of operation. Three cafes provided a collective total of $3 \times 1.32$ gal buckets of organic waste collected per day.

$3 \times 1.32 \mathrm{gal}=3.96 \mathrm{gal}$

3.96 gal $\times 7$ days $=27.72$ gal per week

27.72 gal per week $x 50$ weeks per year (based on a shutdown period over

Christmas) $=1,385$ gal per year

$1 \mathrm{gal}=8.34 \mathrm{lb}$ 
$1,385 \times 8.34=11,551 \mathrm{lb}$ per year

$112 \mathrm{lb}=0.05$ ton therefore

$11,551 / 112 \times 0.05=\mathbf{5 . 1 6}$ tons annually

- Weight of car for comparison: 2019 Jeep Grand Cherokee Laredo 4 door is 4,875 Ibs

$112 \mathrm{lb}=0.05$ ton therefore

$4,875 / 112 \times 0.05=2.18$ tons

5.16 tons annually / 2.18 tons per Jeep Cherokee

$=2.36$ Jeep Cherokees per year equivalent in weight

- Worm casting leachate: (2.11 gal of liquid fertilizer produced, per worm bin every 2 months)

$2.11 \mathrm{gal} \times 7$ operation worm bin= $14.77 \mathrm{gal}$ every 2 months

$14.77 \mathrm{gal} \times \mathrm{6}(12 / 2$ months $)$

$=88.62$ gallons per year

https://www.wormtech.com.au/activ8-biological-fertiliser/

(AUD2,200 for 1,000 L) equals USD1,676 USD for 264 gal [converted using Xe app on April 8 2021]

(88.62/264) x USD1,676

=USD562 savings annually in liquid fertilizer cost for the rooftop garden

- Worm casting leachate: 7.93 gal is converted into worm castings per bin every two months.

$7.93 \mathrm{gal}=66.14$ pounds

$66.14 \times 7$ worm bins $=463$ pounds every two months

$463 \times 6=2,778$ pounds per year

https://www.scrapltd.com.au/product/scrap-bulk-worm-casting/

(AUD396 for 0.8 tonne) equals USD302 for 1764 pounds. [converted using Xe app on April 8 2021]

(2778/1764) x USD302

=USD476 savings annually in organic fertilizer cost for the garden beds in the broader South Eveleigh precinct.

\section{Sources:}

- Car Weight: https://www.edmunds.com/jeep/grand-cherokee/2019/features-specs/

- Worm Farms Hungry Bins: https://www.hungrybin.co.nz/

- Cost of liquid fertilizer: https://www.wormtech.com.au/activ8-biological-fertiliser/

- Cost of compost fertilizer: https://www.scrapltd.com.au/product/scrap-bulk-wormcasting/

\section{Limitations:}

Due to restrictions on local trade and businesses, the cafes in the South Eveleigh Precinct were not fully operational throughout 2020, making it difficult for the researchers to undertake all three semi-structured interviews with the cafe owners as planned. We were only able to confirm the quantitative data provided to us by the research partner and one cafe. 
The worm bins were not yet operating at full capacity. The rooftop garden currently has ten worm bins, however only seven were fully operational during the first year of operation. This is because the South Eveleigh precinct is still in development, with new office buildings being constructed, and the total workforce capacity of the site not yet met. The results suggest that the rooftop garden has the potential to increase their capacity to convert organic food waste, once more people are working within the precinct and the cafes are in full operation.

\section{Social Benefits}

- Promotes, celebrates, and shares Indigenous cultural knowledge and practices through a calendar of 192 cultural workshops, classes and social events with 4,069 in-person attendees during the first 9 months of operation.

- Supports community use and enjoyment, with $80 \%$ of 10 surveyed visitors reporting that they had visited the rooftop garden more than once, while $90 \%$ said they were impressed with the garden. $80 \%$ of visitors said they believe the South Eveleigh Community Rooftop Garden is an important place within the South Eveleigh Precinct.

- Improves understanding of Indigenous Knowledge, with $60 \%$ of 10 surveyed visitors reporting that their understanding of Indigenous Knowledge and Indigenous plant use had improved since visiting the garden. $70 \%$ of those respondents said their understanding of Indigenous relationships to self, others, and place had improved since visiting the garden.

- Positively communicates Indigenous cultural knowledge via social media, with $37 \%$ of Instagram posts from the first 9 months of operation being related to Indigenous Knowledge. Indigenous Knowledge posts received $60 \%$ of "likes" (4,266).

\section{Background:}

We took a multi-method approach to assessing the social benefits of the SECRG to ensure biases from using a single method were overcome and to enhance the credibility of the study and rigor of the study. We found this to be of greater relevance in 2020, due to the limitations placed on us because of the COVID-19 pandemic. The multi-method approach included the triangulation of data from an online survey questionnaire, content social media analysis (Instagram) and a content analysis of events and workshops held at the rooftop garden.

\section{Method:}

We wanted to determine how effective the rooftop garden was at communicating Indigenous Knowledge. In this study, we define 'Indigenous Knowledge' as the cumulative body of sophisticated practices and knowledge derived from sustained and extended periods of interaction with the natural environment. The interactions of these 'knowledges' as understandings, interpretations and meanings are fundamental to the cultural complex (language, classification, resource practices and spirituality) and world-view of Australian Indigenous people (Jones, et al. 2016, p.v). 
Online survey questionnaire: Due to the COVID-19 related restrictions including physical distancing and the closure of the rooftop garden in February 2020, we created an online questionnaire that could be distributed through local businesses within the South Eveleigh precinct. We constructed the questionnaire using the closed-question method to determine the participants' responses to answers the research team had hypothesized. The closedquestion method limits the number of responses participants can provide and therefore is most effective in providing precise, clearly identifiable and easily classified answers.

We used experience management software Qualtrics XM to format the survey questions. We decided on Qualtrics XM because our university had a license and the data is securely stored. Qualtrics XM is an easy platform to use and collecting survey data digitally was new to the research team.

We contacted the administration of the South Eveleigh Community Reference Group and the precinct developer to request distribution to potential participants. The survey was distributed in November 2020. At this stage, the rooftop garden had remained closed since February 2020, and office workers within the South Eveleigh Precinct were still 'working from home' because of the COVID-19 pandemic. We received 10 completed unique questionnaire responses. We used the Qualtrics XM reporting function to help tabulate the data. We determine this situation had a severe impact on our ability to reach a broader participant base for the survey.

Social Media: Methods in social media analysis are relatively new (Kranz 2020), however calculating the total number of 'likes' deduces user engagement by determining the number of times people have affirmed posts related to specific content. We chose Instagram as the social media platform to understand how the users engage with the rooftop garden because the platform is heavily focused on the use of an image to communicate designed spaces. Instagram is easy to use and is popular amongst a wide range of age groups.

We used the hashtag \#yerrabingin to identify the social media content (see Figure 12) for analysis. Yerrabingin was used instead South Eveleigh Rooftop Garden, because up until April 1, 2020, the garden was trading under the business name Yerrabingin. We decided to include Instagram posts since the garden opened, as well as before the garden opened during the construction and promotion phase. We identified a total of 128 Instagram posts during this period. We tabulated the data of each post using Microsoft Excel, by recording the date of the post, the user handle (source), the primary content or feature in the image, the complete suite of hashtags associated with the image, total number of comments and total number of likes. Four recurring themes were identified from the Instagram content. These were;

- Social (food / social activities)

- Garden ( garden and horticulture / green roof)

- Indigenous cultural Knowledge (Indigenous Knowledge sharing (food or plant specific)/ cultural workshops/ cultural interviews)

- Event (event promotion) 
There were seven posts that did not align with any of the themes. We collated these into a miscellaneous category.

Figure 12: Screenshot of a page from the content analysis of Instagram posts with the hashtag \#yerrabngin

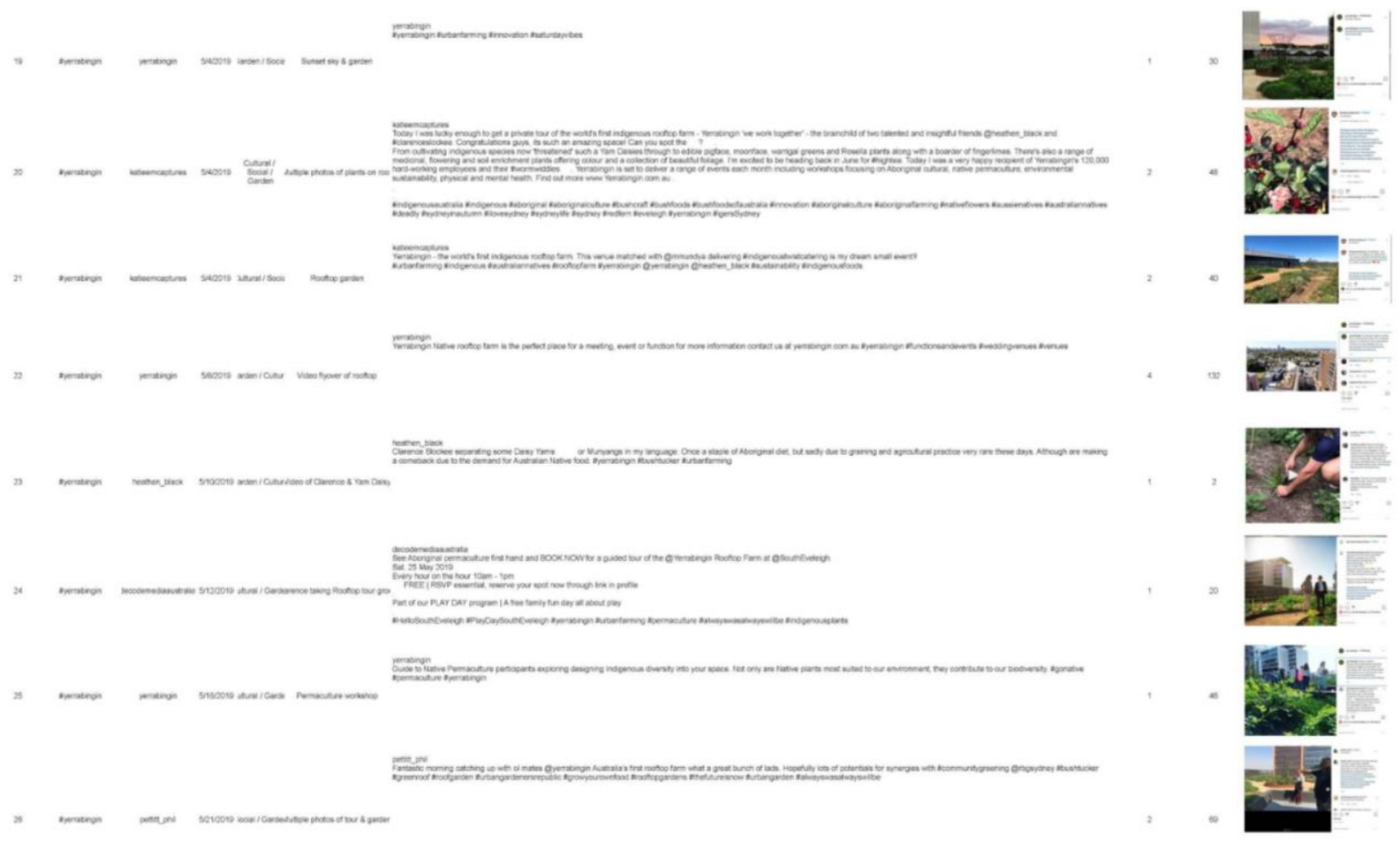

Event calendar: Content analysis is an established method in the social-sciences and is of growing importance for landscape architecture (Raaphorst et al., 2020). Together with our research partner Clarence Slockee (Jiwah), we assessed the event schedule across the first year of operation from opening in April 2019 to the beginning of the COVID-19 pandemic in February 2020. We identified four types of events emerging from the event schedule; tours short or private tours of the garden; workshops - Indigenous cultural Knowledge workshops or wellness events centered around knowledge of native food and drinks; education education operators (group or solo; and community - local social events centered on volunteer engagement. We determined the number of attendees in accordance with one of the four event themes each month and tabulated this data (Table 10).

\begin{tabular}{|l|l|l|l|l|l|l|l|l|}
\hline & $\begin{array}{l}\text { Event } \\
\text { type: } \\
\text { tour }\end{array}$ & $\begin{array}{l}\text { Number } \\
\text { of } \\
\text { people } \\
\text { who } \\
\text { attended }\end{array}$ & $\begin{array}{l}\text { Event type: } \\
\text { workshop }\end{array}$ & $\begin{array}{l}\text { Number } \\
\text { of } \\
\text { people } \\
\text { who } \\
\text { attended }\end{array}$ & $\begin{array}{l}\text { Event } \\
\text { type: } \\
\text { education }\end{array}$ & $\begin{array}{l}\text { Number } \\
\text { of } \\
\text { people } \\
\text { who } \\
\text { attended }\end{array}$ & $\begin{array}{l}\text { Event type: } \\
\text { community }\end{array}$ & $\begin{array}{l}\text { Number of } \\
\text { people } \\
\text { who } \\
\text { attended }\end{array}$ \\
\hline MAY 2019 & 8 & 130 & 3 & 40 & 2 & 25 & 2 & 40 \\
\hline JUNE 2019 & 7 & 110 & 0 & 0 & 2 & 30 & 4 & 55 \\
\hline JULY 2019 & 5 & 89 & 2 & 25 & 0 & 0 & 3 & 70 \\
\hline AUGUST 2019 & 15 & 350 & 16 & 260 & 2 & 45 & 3 & 70 \\
\hline SEPTEMBER 2019 & 7 & 145 & 22 & 455 & 0 & 0 & 3 & 65 \\
\hline
\end{tabular}




\begin{tabular}{|l|l|l|l|l|l|l|l|l|}
\hline OCTOBER 2019 & 4 & 100 & 21 & 415 & 1 & 25 & 5 & 115 \\
\hline NOVEMBER 2019 & 5 & 125 & 16 & 315 & 2 & 60 & 6 & 255 \\
\hline DECEMBER 2019 & 2 & 45 & 11 & 240 & 0 & 0 & 4 & 100 \\
\hline JANUARY 2020 & 2 & 50 & 5 & 100 & 0 & 0 & 2 & 120 \\
\hline TOTALS & $\mathbf{5 5}$ & $\mathbf{1 , 1 4 4}$ & $\mathbf{9 6}$ & $\mathbf{1 , 8 5 0}$ & $\mathbf{9}$ & $\mathbf{1 8 5}$ & $\mathbf{3 2}$ & $\mathbf{8 9 0}$ \\
\hline
\end{tabular}

Source: tabulated data supplied by Clarence Slockee (Jiwah)

Event type segmentation:

TOUR = lunchtime garden tours/ private tours

WORKSHOP = cultural (weaving, native permaculture, foraging, dance)/ Wayapa wellness/ food \& drink

EDUCATION = educational organisation / private

COMMUNITY = local / open day/ volunteer day / social

Table 10: Segmentation of event types and attendance numbers during the first nine months from May 2019 to January 2020.

Figure 13: Segmentation of event types as a percentage

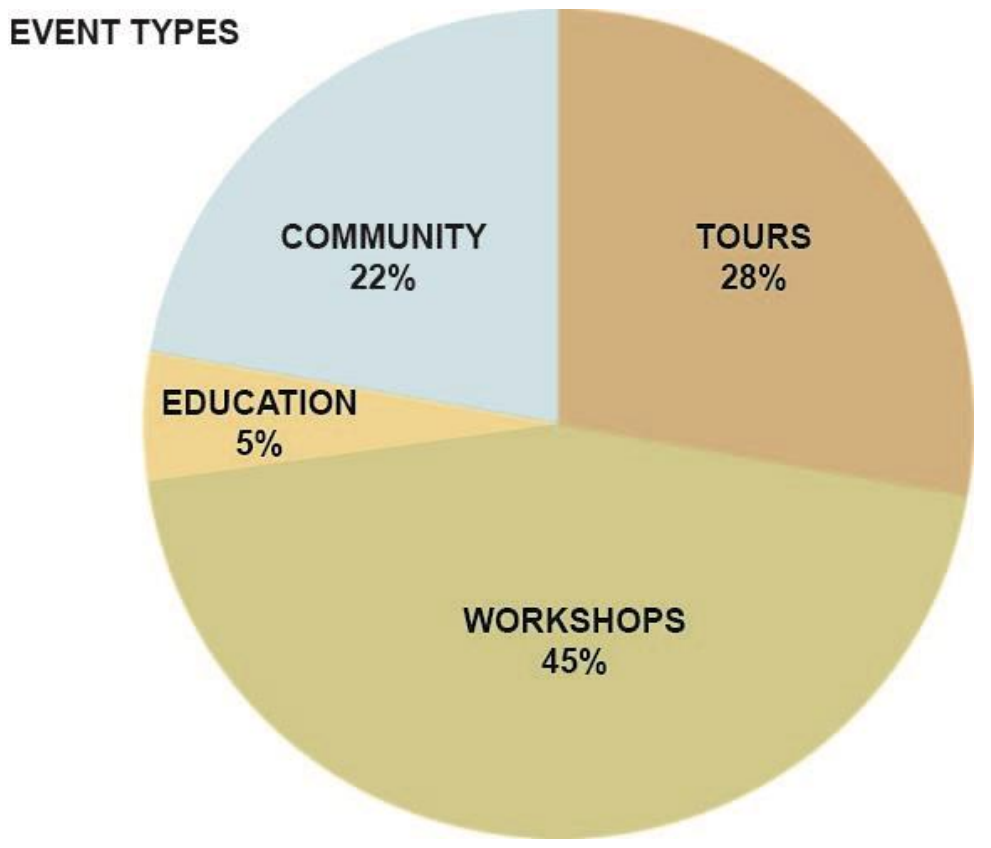

\section{Calculations:}

\section{Online survey questionnaire}

- Eight out of 10 , or $80 \%$ of respondents said they had visited the rooftop garden more than once

- Six out of 10 respondents said their office does not overlook the rooftop. Two of 10, or $20 \%$ said their office overlooks the garden and they enjoyed watching the changes in the garden from their window.

- Six out of 16 , or $37.5 \%$ of participant attendance was for a rooftop garden tour.

- Eight out 10, or $80 \%$ of respondents said they believe South Eveleigh Community Rooftop Garden is an important place within the South Eveleigh Precinct and nine out of 10 or $90 \%$ were impressed with the garden after visiting.

- Six out of 10 , or $60 \%$ of participants said their understanding of Indigenous 
Knowledge has improved since visiting the garden.

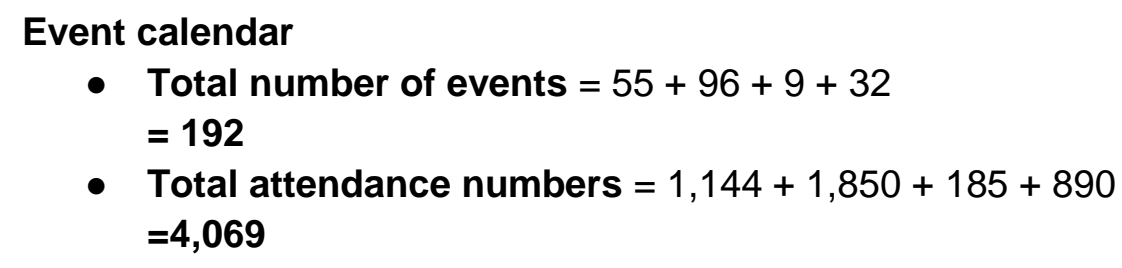

Instagram

- Search term "\#yerrabingin" (from Feb 19 to April 2020)

- Tabulate 128 posts in Microsoft Excel: 376 comments / 8,722 likes

- Tabulate post numbers and impressions based on thematic:

- Social (food / social activities) 30 posts, 1,854 likes.

- Convert to \%: $1,854 / 7,111 \times 100=26.1 \%$

- Garden ( garden and horticulture / green roof) 15 posts, 610 likes

- Convert to \%: $610 / 7,111 \times 100=8.6 \%$

- Indigenous cultural Knowledge (Indigenous Knowledge shared orally (yarning), (food or plant specific)/ cultural workshops/ cultural interviews) 48 posts, 4266 likes

- Convert to \%: 4266/7,111 x $100=60 \%$

- Event (event promotion) 28 posts, 1661 likes

- Convert to \%: $1611 / 7,111 \times 100=22.6 \%$

- Miscellaneous. 7 posts, 381 likes

- Convert to a \%: $381 / 7,111 \times 100=5.4 \%$

\section{Sources:}

- Instagram results Search 1 https://drive.google.com/file/d/1U uPrjinsknbjCtG8Rbz6MxB1yRjBTE5/view?usp=sh aring

- www.instagram.com

- Yerrabingin event attendance records provided by Clarence Slockee (Jiwah)

- Highfield, T., Leaver, T., 2014. A methodology for mapping Instagram hashtags. FM. https://doi.org/10.5210/fm.v20i1.5563

- Raaphorst, K.M.C, Roeleveld, Gerda, Duchhart, I, Knaap, van der, W.G.M, and Brink, van den, A. 'Reading Landscape Design Representations as an Interplay of Validity, Readability and Interactivity: a Framework for Visual Content Analysis'. Visual Communication (London, England) 19, no. 2 (2020): 163-97. Accessed doi:10.1177/1470357218779103.

- Social Media Measuement <https://www.instituteforpr.org/wp-content/uploads/SocialMedia-Measurement-Paper-Jeffrey-6-4-13.pdf>

- Jones et al 2016 "Re-casting terra nullius blindness: empowering Indigenous protocols and knowledge in Australian university built environment education" <http://dro.deakin.edu.au/eserv/DU:30102228/jones-recastingterra-2016.pdf>

\section{Limitations:}

- We were unable to conduct surveys as planned due to Covid-19 restrictions and 
limited timeframe. This led to low response rates for the online survey.

- Some of the record-keeping related to event type or participation numbers was inconsistent. As a result we were unable to calculate the revenue associated with each type.

- It is difficult to segment the events into separate parts, as our research partner notes, some of the events might have addressed two types of events (i.e. education and workshop). Together with the research partners, we made the decision to assign each event to a category that best aligned it with one of the themes.

- The dissolution of the partnership between the Yerrabingin business Directors occurred in early 2020. At this time events ceased. This accounts for no event data being reported from February until April, when the dissolution was formalized.

- In the social media analysis we were not able to account for duplications; for example, of similar entries posted by different users, or on alternate days.

- Provides a variety of learning opportunities and experiences related to Indigenous Knowledge, with 10 external educational program providers and 185 visitors from educational institutions visiting in the first 9 months of operation.

Method: Our research partner was able to extract the event information and attendance records since the rooftop garden's opening and compile these into a Microsoft Excel worksheet. Together with our research partner, we segmented the event information into similar types.

One of the types identified was educational experiences. Education experiences were undertaken by a range of education providers including universities, local schools, Indigenous specific education providers and state government departments. Our research partner was able to identify a range of education experiences undertaken on the rooftop. These education experiences ranged from interviews and tours, to specific Indigenous Knowledge education programs, mentoring programs, cultural workshops and native permaculture demonstrations.

Ten educational providers were differentiated from the event and attendance information. These educational providers are listed below:

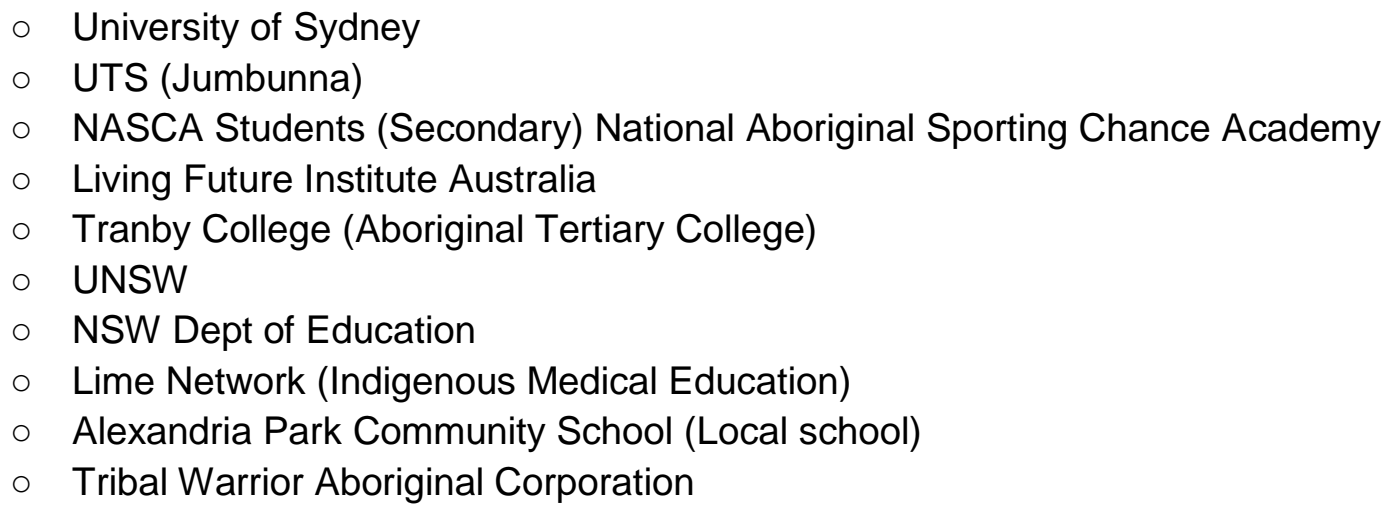

\section{Calculations:}

- Calculate number $(n)$ of educational events and $(y)$ type $(x)$ participants per type and (z) educational providers 
- Number of educational events $(n=9)$

- Number of participants $(x=185)$

- Types of events $(y=5)$

- Educational providers $(z=10)$

\section{Sources:}

- Number of visitors and participants in cultural activities, workshops and events excel spreadsheet supplied by our research partner Clarence Slockee.

- Personal communication. Research Assistant Lisa Thomson and Clarence Slockee, South Eveleigh Community Rooftop Garden, Redfern. 17 June 2020.

- Number of visitors and participants in cultural activities, workshops and events excel spreadsheet supplied by our research partner Clarence Slockee.

\section{Limitations:}

- Our research partner understood the event document was incomplete, and that it was possible that some educational providers were not accounted for.

- COVID-19 restrictions hampered the research team's access to the rooftop and halted the programming that generated additional data on the social benefits of the SECRG is delivering - to visitors and office workers in surrounding buildings of the precinct.

\section{Economic Benefits}

- Provides employment and training opportunities for Aboriginal and Torres Strait Islander People. The rooftop garden's installation created 16 hours of work over 2 days for 4 people. Since its second year of operation, the rooftop garden has offered 16 hours per week of ongoing employment for an Aboriginal person trained in horticulture, maintenance, and operations at a salary of \$11,467 USD per year.

Method: Our research partner provided an early indication that employment opportunities were generated from the construction of the rooftop garden. We undertook several in-person conversations with our research partner to understand the extent of involvement and the limitations. For example, some of the employment that continued post construction was related to the landscape maintenance of the broader South Eveleigh precinct, as well as the rooftop garden. Because we were unable to differentiate and separate the post-construction employment, it was agreed to only report the benefit for the period of construction of the rooftop garden.

From April 2020, a horticulturalist was hired for two days a week to work solely on the rooftop garden, as confirmed by our research partner. This allowed us to report the economic benefit as an ongoing benefit for the second year of operation.

\section{Calculations:}

- Number of days of construction $\times 8$ hour (average working day) $x$ number of people 
employed during installation period of the rooftop farm.

- Annual salary AUD15,000 pa

- Convert to USD $(15,000 \times 0.764)$

- USD11,467 per annum

\section{Sources:}

- Employment records and salary figures supplied by Jiwah and sighted by the research team.

- Personal communication. Lisa Thomson and Clarence Slockee, South Eveleigh Community Rooftop Garden, Redfern. 17 June 2020.

- Personal communication. Sara Padgett Kjaersgaard and Clarence Slockee, South Eveleigh Community Rooftop Garden, Redfern. 2 March 2021 and 14 April 2021

\section{Limitations:}

- Installation period relates only to the hours for the planting of the garden, not for the preparation, construction and installation of the rooftop's sub-structure which was carried out by a separate contractor (Junglefly).

\section{Cost Comparison}

\$26,624 USD is budgeted by the developer for annual maintenance, and this figure is subsidised by income from workshops, events and tours on the rooftop. The original budget for a conventional (not native) rooftop community garden was estimated at $\$ 140,730$ USD in annual maintenance costs. The South Eveleigh Community Rooftop Garden represents a savings of $\$ 140,730$ USD annually or $84 \%$ in maintenance costs compared to the proposed budget for a conventional rooftop green roof garden which would not have been able to contribute to its own upkeep costs.

Background: The green roof at South Eveleigh was always planned to be a conventional community garden (not native) with workshops and market produce available to local workers and residents, however the original proposal included an annual fee of USD167,354 to the developer for management and maintenance. This led the developer to look for more cost-efficient solutions and discussions of the social and cultural benefits of creating a native edible farm with the new Indigneous company who were already commissioned to design a cultural garden within the precinct, with the added benefits of social sustainability by employing and training young Aboriginal people.

A more cost-efficient solution resulted in the development of a cost-neutral business management model, where income from workshops, events and tours covered the employment and training of permanent and casual staff. This business management model greatly reduced maintenance fees down to USD26, 624. The Australian native plants also have much less intensive horticultural requirements than other typical green roof species, typically growing on shallow, infertile soils with no additional irrigation requirements, so they adapt well to the harsh green roof environment. 


\section{Method:}

In conversations with our research partner and the developer, we were able to identify the cost of the original proposal for the rooftop and the cost of the actual rooftop installation and plants. The original proposal was for a generic green roof, which included native and nonnative plant types and was budgeted to include an annual management and maintenance fee of USD167,354.

A significant difference between these two figures is the cost of maintenance, planned for in the original proposal, and the built proposal. The original proposal was for a conventional green roof, which included native and non-native plant types. We compared the cost for the construction and maintenance of the original proposal with those costs incurred by the developer for the first year of operation of the garden.

- Compare the initial alternative proposal's charges for maintenance with the actual costs to Mirvac (the developer) in the first 12 months of operation.

- Compare income/ revenue to costs across the first 12 months of operation.

- The developer provided an indicative cost for the rooftop

\section{Calculations:}

\section{Built Rooftop Garden}

The cost of the rooftop garden was AUD185, 000 plus a goods and services tax of $10 \%$ of the project's value.

Total cost in Australian Dollars including GST = AUD203,500

Convert to US Dollars ( multiply by 0.7607 . Figure derived from XE App on April 12 2021)

$203,500 \times 0.7607=$ USD 155,000

Cost of building the rooftop garden = USD155,000

Cost of plants = AUD12,101

Convert to US Dollars ( multiply by 0.7607 . Figure derived from XE App on April 12 2021)

$10,200 \times 0.7607=$ USD9,205

Cost of native plants $=$ USD9,205

Total cost of built rooftop garden including native plants $=155,000+7,759$

Total cost of built rooftop garden = USD164,205 (rounded to the nearest thousand)

- Calculate the cost per sq foot of the rooftop garden excluding plants 155,000 divided by 6028 sq feet

Cost per sq foot $=$ USD26 (rounded to the nearest dollar)

\section{Annual maintenance cost}

AUD35,000 converted to USD.

$35,000 \times 0.7607=$ USD26, 624 (rounded to the nearest dollar)

Annual maintenance cost $=$ USD26,624 
Annual maintenance cost of original proposal

AUD220,000 convert to USD

$220,000 \times 0.7607=$ USD167,354

Savings in maintenance cost from original proposal to built proposal USD167,354 - USD26,624 = USD140,730

\section{Percentage of cost savings}

$140,730 / 167,354 \times 100=84 \%$ increase in savings

\section{Limitations:}

- Due to commercial in-confidence restrictions, we were provided with an estimate of original costs from the developer, and an estimate (range) of costs from the subconsultant who constructed the rooftop garden. While these figures are not specific, they do provide a range of costs that may be incurred for a similar green roof development, of similar size and scale, within the Sydney area.

- Due to the specificity of Australian native flora and vegetation communities, the rooftop garden cost is unlikely to be replicable to areas outside of Australia, or outside of the south-east Australian bioregion.

- The COVID-19 pandemic resulted in the stoppage of all events, workshops and public access from March 2020.

- Largest source of income from hire of space - AUD3,500 per event. 


\section{Appendix 1}

Full calculations related to Species Richness

Tables 1 to 8: Vegetation volume (flora abundance) for each transect and their associated grid points on the rooftop garden

\begin{tabular}{|c|l|l|l|l|l|}
\hline Grid Reference & \multicolumn{5}{|c|}{ Height variable of vegetation } \\
\hline & $\begin{array}{l}0.0- \\
0.66 \mathrm{ft}\end{array}$ & $\begin{array}{l}0.66- \\
1.64 \mathrm{ft}\end{array}$ & $\begin{array}{l}1.64- \\
3.28 \mathrm{ft}\end{array}$ & $\begin{array}{l}3.28- \\
6.56 \mathrm{ft}\end{array}$ & $>6.56 \mathrm{ft}$ \\
\hline 1 & $\mathrm{xx}$ & $\mathrm{xx}$ & $\mathrm{xx}$ & $\mathrm{x}$ & 0 \\
\hline 2 & 0 & 0 & 0 & 0 & 0 \\
\hline 3 & 0 & 0 & 0 & 0 & 0 \\
\hline 4 & $\mathrm{x}$ & $\mathrm{x}$ & $\mathrm{x}$ & $\mathrm{x}$ & 0 \\
\hline 5 & $\mathrm{x}$ & $\mathrm{x}$ & $\mathrm{x}$ & $\mathrm{x}$ & 0 \\
\hline 6 & $\mathrm{x}$ & 0 & 0 & 0 & 0 \\
\hline 7 & $\mathrm{x}$ & 0 & 0 & 0 & 0 \\
\hline & 6 & 4 & 4 & 3 & 0 \\
\hline $\begin{array}{l}\text { Number of times } \\
\text { vegetation } \\
\text { intercepted the } \\
\text { pole } \\
\text { [Pn1Hx] }\end{array}$ & 6 & & & & \\
\hline \\
x= number of species touching the pole for the specified height variable
\end{tabular}

Table 1: Transect: Orange - grid points 1 to 7

\begin{tabular}{|c|l|l|l|l|l|}
\hline Grid Reference & \multicolumn{5}{|c|}{ Height variable of vegetation } \\
\hline & $\begin{array}{l}0.0- \\
0.66 \mathrm{ft}\end{array}$ & $\begin{array}{l}0.66- \\
1.64 \mathrm{ft}\end{array}$ & $\begin{array}{l}1.64- \\
3.28 \mathrm{ft}\end{array}$ & $\begin{array}{l}3.28- \\
6.56 \mathrm{ft}\end{array}$ & $>6.56 \mathrm{ft}$ \\
\hline 15 & $\mathrm{xx}$ & $\mathrm{xx}$ & $\mathrm{x}$ & 0 & 0 \\
\hline 16 & 0 & 0 & 0 & 0 & 0 \\
\hline 17 & $\mathrm{xx}$ & $\mathrm{xx}$ & $\mathrm{xx}$ & $\mathrm{x}$ & 0 \\
\hline 18 & $\mathrm{xx}$ & $\mathrm{xx}$ & $\mathrm{xx}$ & $\mathrm{xx}$ & $\mathrm{x}$ \\
\hline 19 & 0 & 0 & 0 & 0 & 0 \\
\hline 20 & $\mathrm{x}$ & 0 & 0 & 0 & 0 \\
\hline 21 & $\mathrm{x}$ & $\mathrm{x}$ & $\mathrm{x}$ & 0 & 0 \\
\hline & 8 & 7 & 6 & 3 & 1 \\
\hline $\begin{array}{l}\text { Number of times } \\
\text { vegetation } \\
\text { intercepted the } \\
\text { pole } \\
\text { [Pn1Hx] }\end{array}$ & & & & & \\
\hline $\mathrm{x}=$ number of species touching the pole for the specified height variable \\
\hline
\end{tabular}

Table 3: Transect: Purple - grid points 15 to 21

\begin{tabular}{|c|l|l|l|l|l|}
\hline Grid Reference & \multicolumn{5}{|c|}{ Height variable of vegetation } \\
\hline & $\begin{array}{c}0.0- \\
0.66 \mathrm{ft}\end{array}$ & $\begin{array}{l}0.66- \\
1.64 \mathrm{ft}\end{array}$ & $\begin{array}{l}1.64- \\
3.28 \mathrm{ft}\end{array}$ & $\begin{array}{l}3.28- \\
6.56 \mathrm{ft}\end{array}$ & $>6.56 \mathrm{ft}$ \\
\hline 8 & $\mathrm{x}$ & 0 & 0 & 0 & 0 \\
\hline 9 & $\mathrm{x}$ & 0 & 0 & 0 & 0 \\
\hline 10 & $\mathrm{x}$ & 0 & 0 & 0 & 0 \\
\hline 11 & $\mathrm{x}$ & $\mathrm{x}$ & $\mathrm{x}$ & 0 & 0 \\
\hline 12 & $\mathrm{x}$ & 0 & 0 & 0 & 0 \\
\hline 13 & $\mathrm{x}$ & $\mathrm{x}$ & 0 & 0 & 0 \\
\hline 14 & 0 & 0 & 0 & 0 & \\
\hline \multicolumn{2}{|c|}{} & 2 & 1 & 0 & 0 \\
\hline $\begin{array}{l}\text { Number of times } \\
\text { vegetation } \\
\text { intercepted the } \\
\text { pole } \\
\text { [Pn1Hx] }\end{array}$ & 6 & 2 & & & \\
\hline \\
$\mathrm{x}=$ number of species touching the pole for the specified height variable
\end{tabular}

Table 2: Transect: Red - grid points 8 to 14

\begin{tabular}{|c|l|l|l|l|l|}
\hline Grid Reference & \multicolumn{5}{|c|}{ Height variable of vegetation } \\
\hline & $\begin{array}{l}0.0- \\
0.66 \mathrm{ft}\end{array}$ & $\begin{array}{l}0.66- \\
1.64 \mathrm{ft}\end{array}$ & $\begin{array}{l}1.64- \\
\mathbf{3} .28 \mathrm{ft}\end{array}$ & $\begin{array}{l}3.28- \\
6.56 \mathrm{ft}\end{array}$ & $>6.56 \mathrm{ft}$ \\
\hline 22 & $\mathrm{xx}$ & $\mathrm{xx}$ & $\mathrm{x}$ & 0 & 0 \\
\hline 23 & $\mathrm{x}$ & $\mathrm{x}$ & 0 & 0 & 0 \\
\hline 24 & $\mathrm{xx}$ & 0 & 0 & 0 & 0 \\
\hline 25 & $\mathrm{xx}$ & $\mathrm{x}$ & $\mathrm{x}$ & 0 & 0 \\
\hline 26 & $\mathrm{xxx}$ & $\mathrm{x}$ & 0 & 0 & 0 \\
\hline 27 & $\mathrm{xxx}$ & $\mathrm{x}$ & $\mathrm{x}$ & 0 & 0 \\
\hline 28 & $\mathrm{x}$ & $\mathrm{x}$ & $\mathrm{x}$ & 0 & 0 \\
\hline $\begin{array}{l}\text { Number of times } \\
\text { vegetation } \\
\text { intercepted the } \\
\text { pole } \\
{[\mathrm{Pn} 1 \mathrm{Hx}]}\end{array}$ & 14 & 7 & 4 & 0 & 0 \\
\hline $\mathrm{x}=$ number of species touching the pole for the specified height variable
\end{tabular}

Table 4: Transect: Blue - grid points 22 to 28 


\begin{tabular}{|c|l|l|l|l|l|}
\hline Grid Reference & \multicolumn{5}{|c|}{ Height variable of vegetation } \\
\hline & $\begin{array}{l}0.0- \\
0.66 \mathrm{ft}\end{array}$ & $\begin{array}{l}0.66- \\
1.64 \mathrm{ft}\end{array}$ & $\begin{array}{l}1.64- \\
3.28 \mathrm{ft}\end{array}$ & $\begin{array}{l}3.28- \\
6.56 \mathrm{ft}\end{array}$ & $>6.56 \mathrm{ft}$ \\
\hline 29 & $\mathrm{xx}$ & $\mathrm{xx}$ & $\mathrm{x}$ & 0 & 0 \\
\hline 30 & 0 & 0 & 0 & 0 & 0 \\
\hline 31 & 0 & 0 & 0 & 0 & 0 \\
\hline 32 & 0 & 0 & 0 & 0 & 0 \\
\hline 33 & 0 & 0 & 0 & 0 & 0 \\
\hline 34 & $\mathrm{x} x \mathrm{x}$ & $\mathrm{x}$ & $\mathrm{x}$ & 0 & 0 \\
\hline 35 & $\mathrm{xx}$ & $\mathrm{xx}$ & $\mathrm{xx}$ & $\mathrm{x}$ & 0 \\
\hline & & 5 & 4 & 1 & 0 \\
\hline $\begin{array}{l}\text { Number of times } \\
\text { vegetation } \\
\text { intercepted the } \\
\text { pole } \\
\text { [Pn1Hx] }\end{array}$ & 7 & & & & \\
$\mathrm{x}=$ number of species touching the pole for the specified height variable \\
\hline
\end{tabular}

Table 5: Transect: Green - grid points 29 to 35

\begin{tabular}{|c|c|c|c|c|c|}
\hline \multirow[t]{2}{*}{ Grid Reference } & \multicolumn{5}{|c|}{ Height variable of vegetation } \\
\hline & $\begin{array}{l}0.0- \\
0.66 \mathrm{ft}\end{array}$ & $\begin{array}{l}0.66- \\
1.64 \mathrm{ft}\end{array}$ & $\begin{array}{l}1.64- \\
3.28 \mathrm{ft}\end{array}$ & $\begin{array}{l}3.28 \text { - } \\
6.56 \mathrm{ft}\end{array}$ & $>6.56 \mathrm{ft}$ \\
\hline 43 & $x$ & 0 & 0 & 0 & 0 \\
\hline 44 & 0 & 0 & 0 & 0 & 0 \\
\hline 45 & $x x 0 x x$ & $x x x x$ & $x x x x$ & $x x$ & $x x$ \\
\hline 46 & $x x x x x$ & $x x x x x$ & $x x x x x$ & $x x$ & $x x$ \\
\hline 47 & 0 & 0 & 0 & 0 & 0 \\
\hline 48 & $x x x$ & $x$ & $x$ & 0 & 0 \\
\hline 49 & $x x$ & $\mathrm{xx}$ & $x x$ & 0 & 0 \\
\hline $\begin{array}{l}\text { Number of times } \\
\text { vegetation } \\
\text { intercepted the } \\
\text { pole } \\
{[\mathrm{Pn} 1 \mathrm{Hx}]}\end{array}$ & 19 & 12 & 12 & 4 & 4 \\
\hline
\end{tabular}

Table 7: Transect: Orange - grid points 43 to 49

\begin{tabular}{|c|c|c|c|c|c|}
\hline \multirow[t]{2}{*}{ Grid Reference } & \multicolumn{5}{|c|}{ Height variable of vegetation } \\
\hline & $\begin{array}{l}0.0- \\
0.66 \mathrm{ft}\end{array}$ & $\begin{array}{l}0.66- \\
1.64 \mathrm{ft}\end{array}$ & $\begin{array}{l}1.64- \\
3.28 \mathrm{ft}\end{array}$ & $\begin{array}{l}3.28- \\
6.56 \mathrm{ft}\end{array}$ & $>6.56 \mathrm{ft}$ \\
\hline 36 & 0 & 0 & 0 & 0 & 0 \\
\hline 37 & $x x$ & $\mathrm{x}$ & 0 & 0 & 0 \\
\hline 38 & $x x$ & $x x$ & $\mathrm{x}$ & $\mathrm{x}$ & 0 \\
\hline 39 & $x x$ & 0 & 0 & 0 & 0 \\
\hline 40 & $x$ & 0 & 0 & 0 & 0 \\
\hline 41 & $x x x$ & $x x x$ & $x$ & 0 & 0 \\
\hline 42 & $\mathrm{x}$ & $\mathrm{x}$ & $\mathrm{x}$ & 0 & 0 \\
\hline $\begin{array}{l}\text { Number of times } \\
\text { vegetation } \\
\text { intercepted the } \\
\text { pole } \\
{[\mathrm{Pn} 1 \mathrm{Hx}]}\end{array}$ & 12 & 7 & 3 & 1 & 0 \\
\hline
\end{tabular}

Table 6: Transect: Yellow-grid points 36 to 42

\begin{tabular}{|c|l|l|l|l|l|}
\hline Grid Reference & \multicolumn{5}{|c|}{ Height variable of vegetation } \\
\hline & $\begin{array}{c}0.0- \\
0.66 \mathrm{ft}\end{array}$ & $\begin{array}{l}0.66- \\
1.64 \mathrm{ft}\end{array}$ & $\begin{array}{l}1.64- \\
3.28 \mathrm{ft}\end{array}$ & $\begin{array}{l}3.28- \\
6.56 \mathrm{ft}\end{array}$ & $>6.56 \mathrm{ft}$ \\
\hline 50 & $\mathrm{x}$ & 0 & 0 & 0 & 0 \\
\hline 51 & $\mathrm{xx}$ & $\mathrm{xx}$ & $\mathrm{xx}$ & 0 & 0 \\
\hline 52 & 0 & 0 & 0 & 0 & 0 \\
\hline 53 & 0 & 0 & 0 & 0 & 0 \\
\hline 54 & $\mathrm{xx}$ & $\mathrm{xx}$ & 0 & 0 & 0 \\
\hline 55 & $\mathrm{xx}$ & $\mathrm{x}$ & $\mathrm{x}$ & 0 & 0 \\
\hline 56 & $\mathrm{xx}$ & $\mathrm{x}$ & $\mathrm{x}$ & 0 & 0 \\
\hline & 9 & 6 & 4 & 0 & 0 \\
\hline $\begin{array}{l}\text { Number of times } \\
\text { vegetation } \\
\text { intercepted the } \\
\text { pole } \\
\text { [Pn1Hx] }\end{array}$ & & & & & \\
\hline $\mathrm{x}=$ number of species touching the pole for the specified height variable
\end{tabular}

Table 8: Transect: Red - grid points 50 to 56

Determine the total variable height of vegetation volume across the rooftop

We used the formula identified in Threlfall et al. $(2015$, p.243) to undertake the calculations. We used the original formula in its metric format to work through the calculations.

VvegHx $=((\operatorname{Pn} 1 \mathrm{Hx} / \mathrm{PtH} \mathrm{x}) \mathrm{x}$ VsHx $)$

- Where $\mathrm{Vs}=\mathrm{A}=\pi \mathrm{r} 2=\pi \cdot 0.52 \approx 0.7854$ (the area in sq $\mathrm{m}$ of each grid plot surveyed)

- Where $\mathrm{Hx}$ is the height range for each category

- Where $\mathrm{PtHx}$ is the total number of pole points surveyed. $\mathrm{PtHx}=56$

Pn1Hx for each height interval

0.0-0.66 ft $(0.0-0.2 \mathrm{~m})[\mathrm{Pn} 1 \mathrm{Hx}]=6+6+8+14+7+12+19+9=81$

0.66-1.64 ft $(0.2-0.5 \mathrm{~m})[\mathrm{Pn} 1 \mathrm{Hx}]=4+2+7+7+5+7+12+6=50$ 
1.64-3.28 ft $(0.5-1.0 \mathrm{~m})[\mathrm{Pn} 1 \mathrm{Hx}]=4+1+6+4+4+3+12+4=38$

3.28-6.56 ft $(1.0-2.0 \mathrm{~m})[\mathrm{Pn} 1 \mathrm{Hx}]=3+0+3+0+1+1+4+0=12$

$6.56 \mathrm{ft}<(2.0 \mathrm{~m}<)[\mathrm{Pn} 1 \mathrm{Hx}]=0+0+1+0+0+0+4+0=5$

Vegetation density $(\mathrm{VvegHx})$ for each height variable across the whole rooftop

Vveg $\mathrm{Hx}$ 0.0-0.66 ft [0.0-0.2] $=81 / 56 \times(0.79 \times 0.2)$

Vveg $\mathrm{Hx} 0.0-0.66 \mathrm{ft}[0.0-0.2]=0.228$

$0.228 \times 100=22.8 \%$

Vveg $\mathrm{Hx}$ 0.66-1.64 ft [0.2-0.5] = 50/56 x $(0.79 \times 0.3)$

Vveg $\mathrm{Hx}$ 0.66-1.64 ft [0.2-0.5] $=0.212$

$0.212 \times 100=21.2 \%$

Vveg Hx 1.64-3.28 ft [0.5-1.0] = 38/56 x $(0.79 \times 0.5)$

Vveg $\mathrm{Hx} 1.64-3.28 \mathrm{ft}[0.5-1.0]=0.268$

$0.268 \times 100=26.8 \%$

Vveg Hx 3.28-6.56 ft [1.0-2.0] = 12/56 x $(0.79 \times 1)$

Vveg $\mathrm{Hx}$ 3.28-6.56 ft [1.0-2.0] $=0.169$

$0.169 \times 100=16.9 \%$

Vveg Hx $6.56 \mathrm{ft}<[<2 \mathrm{~m}]=5 / 56 \times(0.79 \times \mathrm{X})(\mathrm{X}$ is infinite)

Vveg $\mathrm{H} \times 6.56 \mathrm{ft}<[<2 \mathrm{~m}]=0.07$

$0.07 \times 100=7.0 \%$ 
Appendix 2: Survey questions

\section{Default Report}

\section{Landscape Architecture Foundation-Case Study Investigation: South Eveleigh Community Rooftop Garden \\ April 22, 2021 7:50 PM MDT}

Q1 - PISCF template online survey South Eveleigh Community Rooftop Garden Please read the Online Participant Information Statement (PISCF) at the link above. If you decide to take part in the research study, we will ask you to complete an online survey. The questionnaire will ask you questions about your experience of the South Eveleigh Community Rooftop Garden (previously Yerrabingin) project through visiting the project site. It should take approximately 10 minutes to complete. Inclusion/Exclusion Criteria Before you decide to participate in this research study, we need to ensure that it is ok for you to take part. The research study is looking recruit people who meet the following criteria: 1) Are 18 years of age By Selecting Agree below. You agree to the terms outlined in the PISCF 
Garden Please read the Online Participant Information Statement (PISCF) at the link above. If you decide to take part in the research

study, we will ask you to complete an online survey. The

questionnaire will ask you questions about your experience of the

South Eveleigh Community Rooftop Garden (previously Yerrabingin) 1

project through visiting the project site. It should take approximately 10 minutes to complete. Inclusion/Exclusion Criteria Before

you decide to participate in this research study, we need to ensure that it is ok for you to take part. The research study is

looking recruit people who meet the following criteria: 1) Are 18 years of age By Selecting Agree below. You agree to the terms outlined in the PISCF

1.001 .001 .000 .000 .0013

Showing rows 1 - 3 of 3

Q2 - How often have visited the South Eveleigh Community Rooftop

Garden (previously Yerrabingin Rooftop Farm) since it opened in April

$219 ? 0$

Never

Once

A couple of times

About once a month

I try and visit

once a week

How often have visited the South Eveleigh Community Rooftop 
Showing rows $1-6$ of 6

Q3 - Which phrase most closely describes your attitude to having a view over looking the green roof? (Choose any or all that apply)

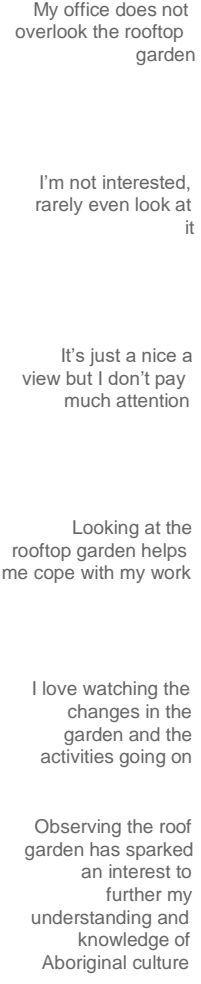


Q4 - When I visited the South Eveleigh Community Rooftop Garden it was for (choose those that apply)

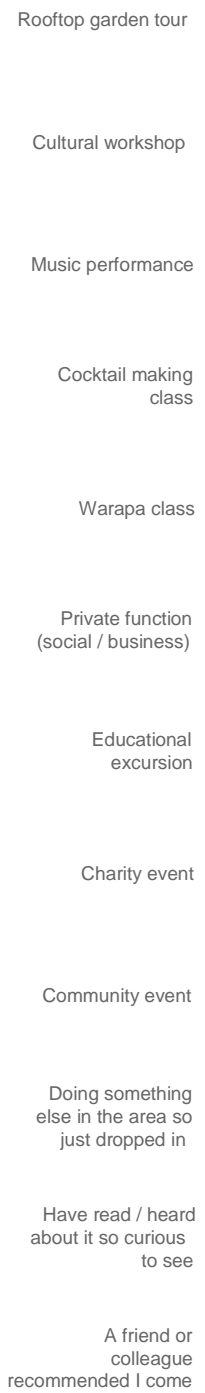

Other

00.511 .522 .533 .544 .555 .566 .5

1 Rooftop garden tour 37.50\% 62 Cultural workshop 12.50\% 23 Music performance $0.00 \% 04$ Cocktail making class $0.00 \%$ 
5 Warapa class $0.00 \% 06$ Private function (social / business) $12.50 \% 27$ Educational excursion $6.25 \% 18$ Charity event $6.25 \%$

19 Community event $0.00 \% 0$

10 Doing something else in the area so just dropped in $0.00 \% 011$ Have read / heard about it so curious to see $12.50 \% 212 \mathrm{~A}$

friend or colleague recommended I come $0.00 \% 013$ Other $12.50 \% 2$

Showing rows $1-14$ of 14

Q5 - South Eveleigh Community Rooftop Garden is an important place

within the South Eveleigh Precinct

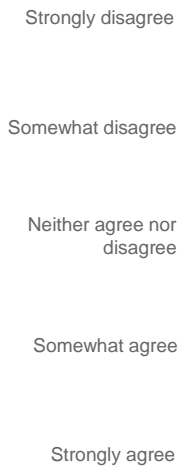


Showing rows $1-6$ of 6

Q7 - If/when I visit the South Eveleigh Community Rooftop Garden I do so primarily for (select as many of those that apply)

Social activity

Respite

Educational

Horticulture/Permacultu

Environmental

Sustainable gardening

$$
\begin{aligned}
& \text { gardening } \\
& \text { practices }
\end{aligned}
$$

Cultural heritage

Indigenous knowledge 
Health and wellbeing

Native food produce

Aesthetic appreciation

Other reasons

00.511 .522 .533 .544 .555 .5

1 Social activity $8.33 \% 32$ Respite 5.56\% 23 Educational 11.11\% 44 Horticulture/Permaculture $8.33 \% 35$ Environmental

$2.78 \% 16$ Sustainable gardening practices $8.33 \% 3$

7 Cultural heritage $8.33 \% 38$ Indigenous knowledge $11.11 \% 49$ Composting/Worm farming $0.00 \% 0$

10 Health and wellbeing 8.33\% 311 Native food produce $8.33 \% 312$ Aesthetic appreciation $13.89 \% 513$ Other reasons $5.56 \%$

Showing rows $1-14$ of 14

Q8 - The following features of the South Eveleigh Community Rooftop

\section{Garden appeal to me}

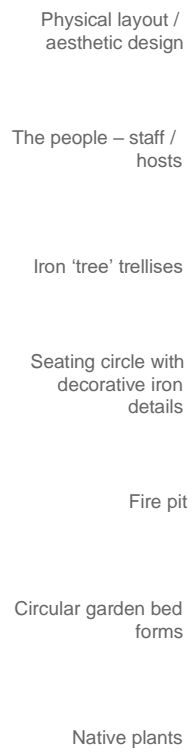

Permaculture 
Catering with native

produce

Views / aspect

ommunity connections

1 Physical layout / aesthetic design 13.33\% 62 The people - staff / hosts $8.89 \% 43$ Iron 'tree' trellises $2.22 \% 14$ Seating circle with decorative iron details $6.67 \% 35$ Fire pit $6.67 \% 36$ Circular garden bed forms $8.89 \% 4$

7 Native plants $17.78 \% 88$ Permaculture $6.67 \% 39$ Native produce / botanicals $8.89 \% 4$

10 Catering with native produce 4.44\% 211 Views / aspect $4.44 \% 212$ Community connections $11.11 \% 5$

Showing rows $1-13$ of 13

Q9 - My understanding of Indigenous Knowledge has improved since visiting the South Eveleigh Community Rooftop Garden.

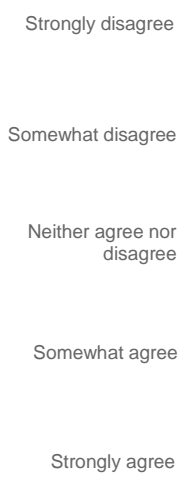


Showing rows $1-6$ of 6

Q10 - My understanding of Indigenous use of plants has improved

since visiting the South Eveleigh Community Rooftop Garden.

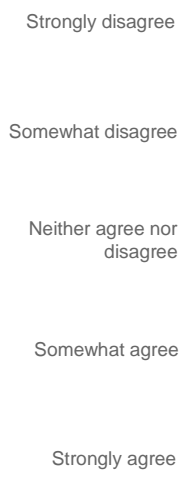

Showing rows 1 - 6 of 6

Q11 - My understanding of Indigenous relationships (to self, others and place) has improved since visiting the South Eveleigh Community Rooftop Garden. 
${ }_{1}$ My understanding of Indigenous storytelling has improved since

visiting the South Eveleigh Community Rooftop Garden3.00 5.00 3.80 0.75 0.5610

1 Strongly disagree $0.00 \% 02$ Somewhat disagree $0.00 \% 03$ Neither agree nor disagree $40.00 \% 44$ Somewhat agree $40.00 \%$ 45 Strongly agree $20.00 \% 2$

Showing rows $1-6$ of 6

\section{End of Report}

